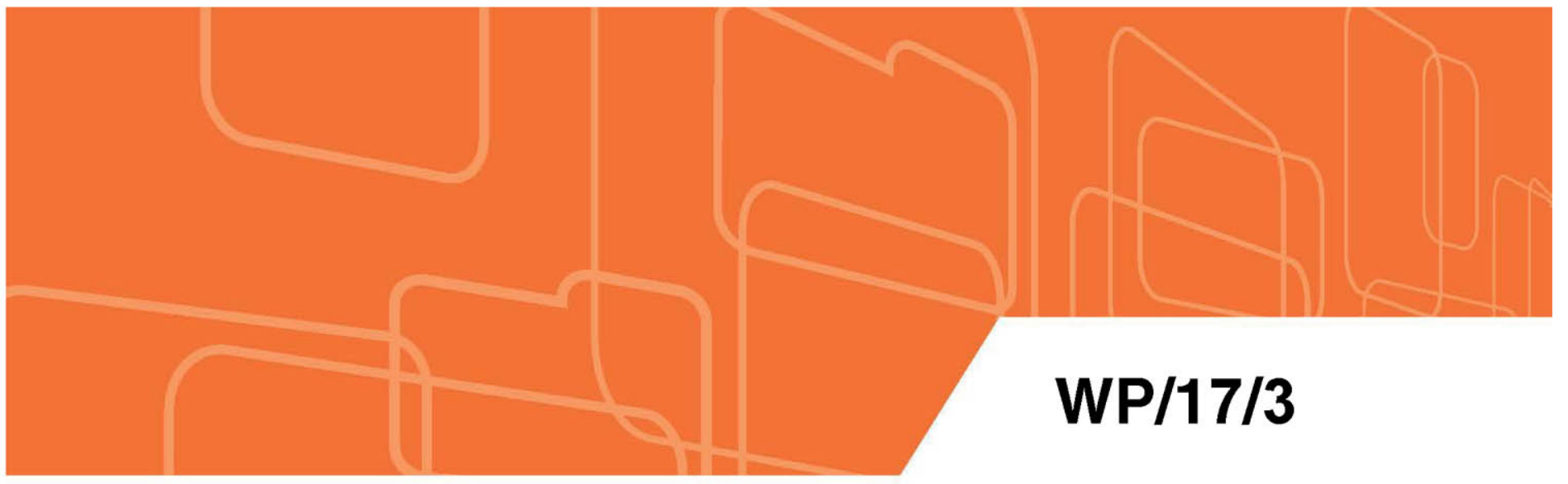

IMF Working Paper

\title{
Why do bank-dependent firms bear interest-rate risk?
}

by Divya Kirti

IMF Working Papers describe research in progress by the author(s) and are published to elicit comments and to encourage debate. The views expressed in IMF Working Papers are those of the author(s) and do not necessarily represent the views of the IMF, its Executive Board, or IMF management. 


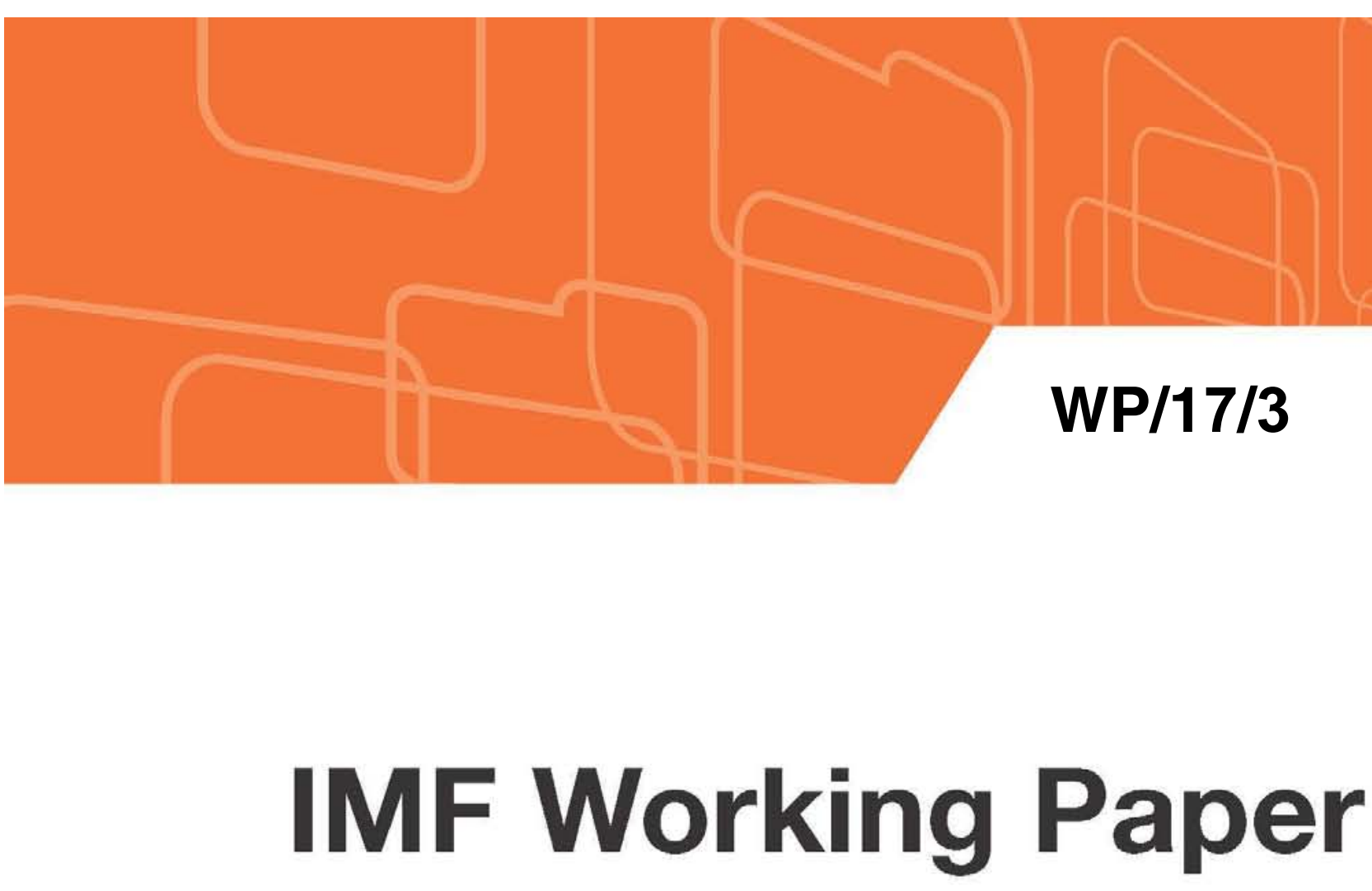

\section{Why do bank-dependent firms bear interest-rate risk?}

by Divya Kirti

IMF Working Papers describe research in progress by the author(s) and are published to elicit comments and to encourage debate. The views expressed in IMF Working Papers are those of the author(s) and do not necessarily represent the views of the IMF, its Executive Board, or IMF management.

I N T E R N A T I O N A L M O N E T A R Y F 


\title{
IMF Working Paper
}

Research Department

\section{Why do bank-dependent firms bear interest-rate risk? \\ Prepared by Divya Kirti}

Authorized for distribution by Maria Soledad Martinez Peria

January 2017

\section{IMF Working Papers describe research in progress by the author(s) and are published to elicit comments and to encourage debate. The views expressed in IMF Working Papers are those of the author(s) and do not necessarily represent the views of the IMF, its Executive Board, or IMF management.}

\begin{abstract}
I document that floating-rate loans from banks (particularly important for bank-dependent firms) drive most variation in firms' exposure to interest rates. I argue that banks lend to firms at floating rates because they themselves have floating-rate liabilities, supporting this with three key findings. Banks with more floating-rate liabilities, first, make more floating-rate loans, second, hold more floating-rate securities, and third, quote lower prices for floating-rate loans. My results establish an important link between intermediaries' funding structure and the types of contracts used by non-financial firms. They also highlight a role for banks in the balance-sheet channel of monetary policy.
\end{abstract}

JEL Classification Numbers: G21, G32, E44

Keywords: Interest-rate risk, corporate finance, bank lending, bank-dependent firms

Author's E-Mail Address: dkirti@imf.org 


\title{
Why do bank-dependent firms bear interest-rate risk?
}

\author{
Divya Kirti*
}

IMF

*Email: dkirti@imf.org. This paper is a revised version of part of my doctoral thesis at Harvard University. I am deeply grateful to my thesis advisors Jeremy Stein, David Scharfstein, John Campbell, Oliver Hart and Adi Sunderam for their guidance. For helpful conversations, I also thank Philippe Aghion, Malcolm Baker, Mark Carey, Sergey Chernenko, William Diamond, Robin Greenwood, Benjamin Hébert, Eben Lazarus, Jing Li, Matteo Maggiori, Vijay Narasiman, Adriano Rampini, Ran Shorrer, Til Schuermann, Paul Tucker, Boris Vallée, Lucy White, Yao Zeng, Luigi Zingales, and especially Benjamin Friedman, Sam Hanson and Andrei Shleifer. I am grateful for funding from the Macro Financial Modeling Group and the Hirtle Callaghan grant to Harvard. Frederik Bruggink, Nicholas Gutmann, Craig Slater, and Milly Wang provided able research assistance. The internet appendix to this paper is available on request. 


\section{Contents}

1 Introduction $\quad \underline{1}$

2 Firms' exposure to interest-rate risk $\underline{\mathbf{6}}$

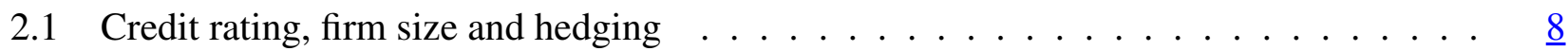

3 Theoretical framework $\quad \underline{10}$

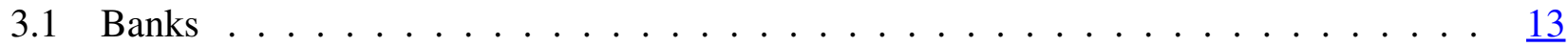

3.2 Bank-dependent firms . . . . . . . . . . . . . . . . 16

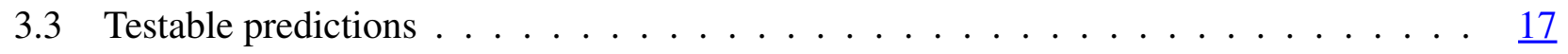

4 Empirics: main results $\quad \underline{20}$

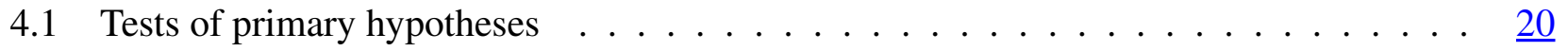

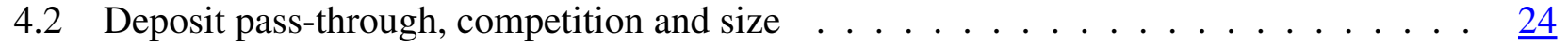

4.3 Time series analysis $\ldots \ldots \ldots \ldots \ldots \ldots \ldots$

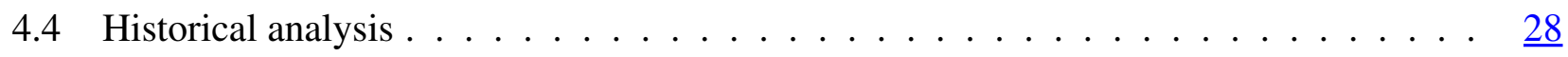

5 Implications for transmission of monetary policy $\quad \underline{30}$

6 Conclusion $\quad \underline{32}$

$\begin{array}{lr}\text { A Tables and Figures } & \underline{\mathbf{3 8}}\end{array}$ 


\section{Introduction}

Firms vary widely in their exposure to interest-rate risk. I document that while some firms are largely financed with fixed-rate debt, others are primarily financed with floating-rate debt. The choice of interest-rate exposure matters in the presence of financial frictions: when rates rise, floating-rate debt creates cash-flow shocks that can have real effects on financially constrained firms' investment (Fazzari, Hubbard \& Petersen 1988, Froot, Scharfstein \& Stein 1993, Stulz 2003). Why are some firms more exposed to floating rates than others? One view is that firms demand different levels of exposure to match the characteristics of their cash flows and assets. In this paper, I focus on an alternative, supplydriven view that some firms - those that are dependent on banks for financing - borrow at floating rates because of the way banks themselves are financed. Banks offer floating-rate loans at lower cost because these loans help them match the interest-rate exposure of their own short-term liabilities.

Consistent with this supply-driven view, I document that bank dependence is the single dominant driver of firms' use of floating debt. To show this, I combine detailed data on firms' debt structure from Capital IQ with manually collected data on their use of interest-rate swaps. ${ }^{1}$ Three facts point to bank dependence as the main driver of firms' exposure to interest rates. First, the correlation between firms' floating fraction of debt and the fraction of their debt from banks is high. Second, firms that borrow from banks appear bank dependent, rather than predisposed towards floating rates: they have poorer credit ratings and are smaller - and therefore are more likely to require bank monitoring (Rauh \& Sufi 2010, Diamond 1984, Tirole 2006) - but they do not have more cyclical cash flows. Third, when these bank-dependent firms use interest-rate swaps, they use them to reduce exposure to short-term interest rate fluctuations, although only partially.

Why should bank dependence drive firms' exposure to interest-rate risk? The answer lies in the observation that banking involves a fundamental maturity mismatch, as banks finance firms' longterm projects with short-term, interest-bearing deposits. ${ }^{2}$ Because firms' cash flows are only weakly

\footnotetext{
${ }^{1}$ I collect data on firms' use of interest-rate swaps from SEC filings for a sample of almost 5,000 firm-years.

${ }^{2}$ Bank lending to firms largely consists of term loans, with similar maturities to corporate bonds, rather than short-term loans. Fixed interest rates on bank loans would subject banks to interest-rate mismatch. Banks fund themselves with deposits despite this mismatch because deposits provide liquidity services, and are therefore cheap (Gorton \& Pennacchi 1990, Gorton 2010, Diamond \& Dybvig 1983, Stein 2012).
} 
correlated with interest rates, this leads to an interest-rate mismatch between firms' output and banks' liabilities. ${ }^{3}$ I use a simple model to show that banks prefer not to bear this mismatch themselves when external finance and hedging are both costly. Costly external finance makes banks effectively risk averse regarding asset-liability interest-rate mismatch (Froot et al. 1993, Stulz 2003). ${ }^{4}$ Moreover, as suggested in a growing literature (Rampini \& Viswanathan 2010, Rampini, Viswanathan \& Vuillemey 2015, Rampini, Sufi \& Viswanathan 2014, Ivashina, Scharfstein \& Stein 2015, Bolton \& Oehmke 2015), collateral requirements make hedging costly, preventing banks from using derivatives to fully hedge exposure to interest rates. I model the opportunity cost of collateral as reduced investment in projects with concave returns, which leads to convex costs of hedging, following Ivashina et al. (2015). ${ }^{5}$ Convex costs of hedging mean that even if the first dollar of hedging is cheaper for banks (than for firms), hedging a significant portion of the balance sheet need not be cheaper. Due to their deposit-taking role, and finite ability to transform short duration liabilities into long duration assets, banks must have some role in explaining variation in firms' exposure to interest rates.

A key implication of this framework, in which banks' liability structure drives the interest-rate exposure of their assets, is that banks with more floating-rate liabilities should make more floating-rate loans. In aggregate, as banks are largely deposit funded, a substantial portion of loans to firms are floating-rate. I take the standard approach of using cross-sectional variation to make inferences about this aggregate pattern. I use variation in deposit pass-through, the extent to which banks pass on changes in short-term interest rates to depositors, to measure the extent to which banks' liabilities are floating rate. Consistent with the framework I describe above, banks with greater deposit pass-through do make more floating-rate loans; a bank with one standard deviation higher deposit pass-through extends four

\footnotetext{
${ }^{3}$ Floating rates also provide a way to write inflation-indexed contracts, which matters when inflation is volatile (one reason floating debt may be more common internationally). This is not relevant for the US where inflation has been low and stable, and changes in nominal rates correspond with changes in real rates.

${ }^{4}$ Banks behave as if they are highly risk averse: bank net interest margins have historically been very stable, despite significant leverage (Flannery 1981, English 2002, English, Van den Heuvel \& Zakrajšek 2013). This literature focuses on commercial banks - the 1980s S\&L crisis illustrates that interest-rate risk can matter for banking institutions.

${ }^{5}$ Convex collateral costs of hedging, which apply to firms as well as banks, explain why bank-dependent firms have more post-hedging exposure to interest rates than firms with better access to capital markets, even though both sets of firms use swaps. This connects with the empirical literature on how firms (Campbell \& Kracaw 1993, Tufano 1996, Guay \& Kothari 2003, Bodnar, Graham, Harvey \& Marston 2011, Chernenko \& Faulkender 2011, Bretscher, Mueller, Schmid \& Vedolin 2015) and banks (Begenau, Piazzesi \& Schneider 2015, Rampini et al. 2015) use derivatives.
} 
percentage points more of its loans at floating rates. One natural concern is that banks endogenously position their liabilities to match the characteristics of their assets. I partially address this concern by showing that my findings are robust to 'instrumenting' for deposit pass-through with measures of deposit competition; the component of deposit liabilities explained by competition also helps explain the extent to which banks make floating-rate loans. ${ }^{6}$ Some identification concerns do remain, as banks with more floating liabilities might also make more floating-rate loans if they match with borrowers that demand them.

To rule out this demand-driven view I follow two conceptual strategies. The first strategy exploits the observation that while the demand- and supply-driven views make consistent predictions regarding banks' loan portfolios, they make opposing predictions regarding banks' securities holdings. Under the supply-driven view, banks with higher deposit pass-through should hold more floating-rate securities, in addition to making floating-rate loans, to reduce asset-liability mismatch. In contrast, banks facing higher demand for floating-rate loans should hold more fixed-rate securities to reduce interest-rate mismatch between loans and liabilities. With both OLS and IV regressions, I show that banks with more deposit pass-through hold more floating-rate securities. This fact is at odds with the view that banks with greater deposit pass-through match with firms demanding floating rates.

With the second strategy, I examine variation in prices in addition to the variation in quantities I describe above. Variation in prices (interest rates on loans) further supports the supply-driven view: banks with more deposit pass-through quote larger interest-rate spreads between fixed-rate mortgages and adjustable-rate mortgages (larger FRM-ARM spreads). ${ }^{7}$ This means that banks with more floating liabilities hold higher quantities of floating-rate loans, at lower interest rates (lower prices), relative to fixed-rate loans. The cross-sectional combination of higher quantities and lower prices points to variation in supply rather than demand. In summary, evidence from three quite different parts of bank balance sheets (loans to firms, mortgages and securities) shows that supply-side effects play a role in determining firms' exposure to interest rates. ${ }^{8}$

\footnotetext{
${ }^{6}$ I use branch level data on bank deposits to calculate measures of deposit concentration, following Drechsler, Savov \& Schnabl (2014), as well as an older literature (Berger \& Hannan 1989, Neumark \& Sharpe 1992).

${ }^{7}$ Banks may also use non-price channels, as Foà, Gambacorta, Guiso \& Mistrulli (2015) argue Italian banks do.

${ }^{8}$ I show that supply shocks are more important than demand shocks in explaining cross-sectional variation in outcomes,
} 
Historical data provides additional evidence of the relationship between banks' liabilities and the interest-rate exposure of their assets. Prior to about 1970, deposits were largely non-interest-bearing, and hence also effectively fixed rate. In this period, floating-rate lending, and not fixed-rate lending, would have been risky for banks. If loans were nevertheless extended primarily at floating rates, this would suggest a different explanation for floating-rate bank lending more recently. Consistent with my argument, I show that in this period implied interest rates on loans were far less sensitive to short-term interest rates than they are today, suggesting that loans were effectively less floating.

My results have implications for how monetary policy is transmitted to firms: bank-dependent firms' exposure to floating rates is a component of the Bernanke \& Gertler (1995) balance-sheet channel of monetary policy. Bernanke \& Gertler (1995) show that firms' financial health weakens when rates rise, as interest expense rises relative to cash flows, and connect this to the effect of monetary policy on business fixed investment. They focus on the interest expense of commercial paper issued by large investment-grade firms. I show that interest expense rises more directly for bank-dependent firms when rates rise, because of their floating-rate bank loans. ${ }^{9}$ My results show that banks play a role in the transmission of monetary policy to firms beyond the usual bank-lending channel (Kashyap \& Stein 1994, Kashyap \& Stein 2000, Peek \& Rosengren 2013) or the more recent deposits channel (Drechsler et al. 2014), as my effect is based on existing rather than new bank lending. ${ }^{10}$ In complementary work, Ippolito, Ozdagli \& Perez (2015) also connect floating-rate bank lending to monetary policy, but do not explain why bank debt is floating rate.

My argument that bank liabilities drive floating-rate bank lending to firms adds to the intermediation literature. It establishes an important link between intermediaries' funding structure and the types of contracts used by non-financial firms. In aggregate, a significant fraction of bank assets are floating

analogously to the seminal work of Working (1927). In Internet Appendix B.2, I outline a framework to think about the relative importance of supply and demand based on the correlation between the floating fractions of loans and securities, using equilibrium expressions for these fractions from the model.

${ }^{9}$ Floating-rate bank loans may provide a natural hedge for bank-dependent firms if they tend to be more financially constrained at times when central banks are likely to lower rates. These firms do use derivatives to (partially) hedge their exposure, suggesting concern about the potential costs of floating-rate debt.

${ }^{10}$ This channel is analogous to the role of ARMs documented by Di Maggio, Kermani \& Ramcharan (2015), Keys, Piskorski, Seru \& Yao (2014), Auclert (2015), Sufi (2015) and Calza, Monacelli \& Stracca (2013). 
rate, and banks do not appear to face significant asset-liability interest-rate mismatch. ${ }^{11}$ I show that banks achieve this, at least in part, by passing interest-rate risk on to firms. Two recent papers advance related arguments: Ivashina et al. (2015) argue that hedging frictions make it advantageous for banks to lend in the same currency as their deposit financing. Hanson, Shleifer, Stein \& Vishny (2014) argue that the types of assets intermediaries hold depend on the stability of their funding. More broadly, my argument is also connected with the view that there are synergies between deposits and commitments (Kashyap, Rajan \& Stein 2002), and that intermediaries must themselves be incentivized to monitor (Diamond 1984, Holmström \& Tirole 1998). This paper highlights the impact of the interest-rate exposure of intermediaries' funding structure on the types of contracts used by non-financial firms.

My results are of particular policy interest given renewed regulatory interest in banks' exposure to interest rates. ${ }^{12}$ This paper suggests that loans to firms reduce interest-rate risk for banks, at the cost of passing it on to bank-dependent firms. Tighter regulation of banks' exposure to interest rates may have therefore unintended effects: it might lead banks to pass on more risk to bank-dependent firms than they do already.

The remainder of the paper is organized as follows: Section 2 shows that bank-dependent firms are exposed to interest rates through floating-rate bank loans. Section 3 lays out the theoretical framework, and highlights testable implications for bank balance sheets. Section 4 presents the main empirical results. It shows that banks with more floating liabilities make more floating-rate loans, hold more floating-rate securities, and quote larger FRM-ARM spreads, showing that variation in firms' exposure to interest rates is driven, at least partially, by supply rather than demand. It also presents several additional results supporting this supply-driven explanation of floating-rate bank lending to firms. Section 5 draws out the implications of my results for monetary policy. Section 6 concludes.

\footnotetext{
${ }^{11}$ About $40 \%$ of all loans and securities have floating rates as of 2014Q4, including mortgage related instruments.

${ }^{12}$ The BCBS is promulgating new regulations regarding interest-rate risk, and the BIS and FDIC argue that banks' exposure to interest-rate risk is growing.
} 


\section{Firms' exposure to interest-rate risk}

This section describes variation in firms' exposure to interest-rate risk through their debt. I show that firms with poorer credit ratings and smaller firms are more exposed, through bank debt. Several features of this variation suggest it is driven by bank dependence rather than preference for floating-rate debt, in particular that bank debt is the primary driver of variation in firms' exposure. I begin by describing my data on firms' capital structure, including manually collected data on firms' use of interest-rate swaps, and then move on to the facts on firms' exposure.

I construct a comprehensive data set on firms' capital structure, augmenting standard balance sheet data from Compustat with detailed data on firms' debt structure from Capital IQ and manually collected data on firms' use of swaps. Capital IQ data provides information on whether debt is fixed or floating rate, at the instrument level. I aggregate instrument level information to the firm level to directly analyze sources of floating-rate debt. I restrict the analysis to firms headquartered in the United States. The data is annual, going from 2003-2013, with about 13,500 firm-year observations, for about 2,200 firms. I also manually collect quantitative data on how firms use interest-rate swaps from SEC filings. The data on swaps covers almost 5,000 firm-year observations, for around 600 firms. The Internet Appendix describes the data construction and collection process as well as variable definitions. ${ }^{13}$

I begin with summary statistics, showing the relevance of floating-rate debt and bank debt, and that firms' cash flows are only weakly cyclical. Panel A of Table 1 shows summary statistics for the full sample. Floating-rate debt and bank debt are important parts of firms' capital structure, comprising $38 \%$ and $43 \%$ of firms' debt respectively. Leverage, measured by the ratio of debt to assets, is on average $33 \%$. I measure the cyclicality of firms' cash flows with a cash-flow beta. ${ }^{14}$ On average, firms

\footnotetext{
${ }^{13}$ See Internet Appendices C.1 and C.2. I thank Adi Sunderam and Sergey Chernenko for sharing their data, which constitutes a portion of the swaps sample. I collect additional data on usage of interest-rate swaps. Out of the 571 firms in my sample, 381 (two thirds) use interest-rate swaps at some point. Interest-rate swaps are the main instrument non-financial firms use to hedge interest-rate risk. Firms do also mention interest rate caps and, in rare instances, other instruments in their SEC filings. To my knowledge, Chernenko \& Faulkender (2011) and Bretscher et al. (2015) are the only other authors to have collected a panel of this type. Several authors including Ippolito et al. (2015) have performed text searches to separate users of derivatives from non-users.

${ }^{14}$ This is a coefficient from firm level regressions of operating income before depreciation, as a fraction of assets, on LIBOR. As is appropriate, I use a measure of cash flow before interest expense is taken into account. Estimating the beta with regressions in changes produces the same qualitative results.
} 
have slightly positively cyclical cash flows. ${ }^{15}$ Panel B shows summary statistics for the sub-sample of firms for which I have information on derivatives. Firms in this sample are larger on average, and have slightly less bank debt.

While investment grade and large firms are primarily funded with fixed-rate corporate bonds, firms with poor credit ratings and smaller firms borrow more through floating-rate bank term loans. Figure 1 shows average debt capital structure. Panel A divides firms by credit rating. Investment grade firms borrow primarily via fixed-rate corporate bonds (omitted from the figure). They also borrow using short-term commercial paper to some extent, and are the only types of firms to do so. ${ }^{16}$ Firms rated as speculative, or unrated, borrow more from banks. Panel B shows firms by size tercile (assigned within year). Small firms also borrow more from banks. Importantly, this bank debt is largely extended at floating rates, with interest rates typically reset every three months. ${ }^{17}$ This is not mechanical: bank lending largely consists of term loans, which, unlike short-term loans, do not have to be floating rate. Indeed, bank loans and corporate bonds have similar maturities.

Bank debt is the primary driver of firm level variation in firms' exposure to interest rates through debt. I present results from firm level regressions in Table 2 to show this. ${ }^{18}$ I begin with cross-sectional analysis, collapsing the sample to means at the firm level. The outcome variable is the fraction of debt that is floating rate (including commercial paper). The most important determinant of how much of a non-financial firm's debt is floating rate is how much of its debt is bank debt. This variable alone leads to an $R^{2}$ of close to $50 \% .{ }^{19}$ Adding variables leads to a negligible improvement in model fit. Table 2 shows that bank debt is also the primary driver of time series variation, using regressions with firm fixed effects. ${ }^{20}$

\footnotetext{
${ }^{15}$ On average, cash flows rise by about 20 basis points as a fraction of assets when LIBOR rises by 1 percentage point. The corresponding fraction for the median firm is 10 basis points.

${ }^{16}$ Large firms with poor credit ratings use several types of debt, while very well rated or unrated firms tend to use only corporate bonds and bank debt respectively (Rauh \& Sufi 2010, Colla, Ippolito \& Li 2013).

${ }^{17}$ Most floating-rate bank debt is indexed to the three month tenor of LIBOR, with rates actually resetting every three months. Occasionally, other tenors are used, and some contracts allow firms to choose the reset frequency.

${ }^{18}$ Internet Appendix C.1 provides variable definitions.

${ }^{19}$ In my data, about $75-80 \%$ of bank loans to firms are floating rate. The FRB's E2 survey provides another data point on this. It shows that in the past $15-20$ years, about $70-80 \%$ of new C\&I lending matures or reprices in less than one month, while the vast majority matures or reprices in less than one year (Vickery 2005). Ippolito et al. (2015) also document similar patterns. Becker, Bos \& Roszbach (2015) document that Swedish banks effectively lend largely at floating rates.

${ }^{20}$ In specifications with firm fixed effects, I double cluster standard errors by firm and year (Thompson 2011). This
} 
Firms' use of floating-rate debt is not systematically related to the cyclicality of their cash flows. This is not consistent with the demand-driven view that firms take on exposure to interest rates to match the characteristics of their cash flows. If firms chose floating-rate debt to match greater cashflow sensitivity to interest rates, cash-flow betas would be strongly positively related to the floating fraction of debt. However, as Table 2 shows, co-movement of firms' cash flows with interest rates is not meaningfully related to the fraction of floating debt in the cross section. ${ }^{21}$ These firms are likely to have bank debt not because of its floating-rate nature, but because they need bank financing.

\subsection{Credit rating, firm size and hedging}

Through a combination of greater initial exposure, partial hedging, and more leverage, firms with poor credit ratings and smaller firms are more exposed to interest-rate risk than investment grade and larger firms. There is a noticeable increase in exposure around the investment grade cutoff, supporting the idea that bank dependence is a key driver.

Firms with poorer credit ratings and smaller firms have more floating-rate debt, both as a fraction of debt and as a fraction of assets. I begin with the full sample of firms, initially focusing on exposure before hedging. Panel A of Table 3 first shows regressions for firms separated by credit rating, including dummies for high yield and unrated firm-years (investment grade firm-years are the omitted category). There are three outcome variables: floating-rate debt as a fraction of debt, the debt to assets ratio, and floating-rate debt as a fraction of assets. Relative to investment grade firms, high yield and unrated firms have more floating-rate exposure, both as a fraction of debt and as a fraction of assets. Panel A also shows that smaller firms have more exposure, in similar regressions separating firms into three categories by size.

I plot exposure for firms separated into credit rating groups, to visually depict the importance of credit rating. I categorize firms into six coarse rating groups ranging from GG to U. Groups labeled IG and HY combine the three closest ratings on either side of the investment grade/high yield cutoff.

accounts for correlation across years within firm, as well as correlation across firms within year.

${ }^{21}$ The relationship is also not statistically significant if I estimate a cash-flow beta based on operating income net of capital expenditure, following Chernenko \& Faulkender (2011). 
Figure 2 looks at exposure before the impact of hedging. Panels A and B show floating debt as a fraction of debt and assets respectively. By both measures, there is a noticeable jump in exposure at the cutoff. Note that firms with the best credit ratings have exposure primarily through commercial paper.

Firms' exposure to floating rates jumps significantly at the cutoff between investment grade and high yield ratings. Panel B of Table 3 restricts the sample to firms with the lowest investment grade rating (BBB-) or the highest high yield rating $(\mathrm{BB}+)$. I include a dummy for $\mathrm{BB}+$ firms; $\mathrm{BBB}-$ firms are the omitted category. Relative to BBB- firms, BB+ firms have more floating debt both as a fraction of debt and as a fraction of assets. They also have more leverage. These patterns are consistent across year and industry: indeed, these regressions include both industry and year fixed effects. This likely reflects that institutions such as insurance companies and pension funds frequently have requirements to invest in, or strong preferences for, investment grade bonds. ${ }^{22}$

While firms do hedge their exposure partially, firms with poorer credit ratings and smaller firms continue to have more exposure to floating rates even after taking hedging into account. Table 4 shows how exposure to interest rates varies with rating and size post-hedging (Panel A splits firms by rating, and Panel B by size). ${ }^{23}$ These regressions show five outcome variables: the floating fraction of debt, net pay-fixed interest-rate swaps as a fraction of debt, post-hedging floating fraction of debt, the debt to assets ratio and post-hedging floating debt as a fraction of assets. Panel A of Table 4 shows that both high yield and unrated firms have more exposure to interest rates, through a combination of more floating debt, partial hedging, and for high yield firms, greater leverage. Investment grade firms use swaps to increase their exposure to interest rates. ${ }^{24}$ A comparison with Panel A of Table 3 shows that the post-hedging difference in net floating-rate debt as a fraction of assets is roughly half the prehedging difference. Panel B of Table 4 shows that, like poorly rated firms, smaller firms also have more exposure to interest rates than large firms.

I also plot firms' exposure within the hedging sample to visually depict that firms do hedge, but

\footnotetext{
${ }^{22}$ In addition to a preference for low credit-risk exposure, these institutions do of course have a preference for assets providing significant duration exposure.

${ }^{23}$ Firms often use interest-rate derivatives to modify their exposure, principally interest-rate swaps. I manually collect data on usage of interest-rate swaps from SEC filings for about $40 \%$ of the relevant sample.

${ }^{24}$ This pattern has been discussed in the literature for some time, with varying interpretations (Bicksler \& Chen 1986, Titman 1992, Bretscher et al. 2015).
} 
only partially. Figure 3 shows firms separated into the same six ratings groups as in Figure 2. Panel A of Figure 3 shows floating debt as a fraction of debt (pre-hedging for comparability). ${ }^{25}$ Panel B shows floating-rate debt, post hedging, as a fraction of assets. A comparison with Panel B of Figure 2 shows that firms with poorer credit ratings do hedge towards levels of exposure faced by better rated firms, but only partially. There is a noticeable jump in post-hedging exposure for firms at the investment grade/high yield cutoff.

To summarize, bank-dependent firms, i.e. firms with poor credit ratings and small firms, have more floating-rate bank debt. While they hedge the resulting interest-rate exposure with interest-rate swaps, they only do so partially. These firms are more exposed to interest rates through floating-rate debt than firms with better access to capital markets. This exposure seems to be driven by a need for bank financing: it consists primarily of bank debt, and is not matched by greater cash-flow sensitivity to interest rates.

\section{Theoretical framework}

This section presents a theoretical framework for understanding why banks pass interest-rate risk on to firms. I use the framework to make three main points regarding my argument that floating-rate bank liabilities drive floating-rate bank lending to firms. First, banks with more floating-rate liabilities should make more floating loans. Second, banks' securities holdings can allow me to rule out the idea that these banks match with firms demanding floating-rate loans. Third, collateral costs prevent firms and banks from hedging fully with derivatives.

I take the basic interest-rate mismatch involved in bank lending to firms as my starting point. Bankdependent firms need to borrow from banks, because they need monitoring to raise sufficient external finance to invest (Diamond 1984, Holmström \& Tirole 1998, Tirole 2006). Firms need external finance to fund long-term projects, requiring long-term finance. ${ }^{26}$ However, the banking system ultimately

\footnotetext{
${ }^{25}$ This initial exposure is very similar to the full sample (Panel A of Figure 2), with the exception of firms with the best ratings - the derivatives sample contains fewer firms with significant commercial paper.

${ }^{26}$ Many long-term projects produce little cash flow in the interim, which would make interim repayment difficult. Shortterm finance would expose firms to rollover risk in addition to interest-rate risk.
} 
funds these long-term projects with short-term interest-bearing deposits. It does so despite the interestrate risk involved because deposits provide liquidity services, and are therefore cheap (Diamond \& Dybvig 1983, Gorton 2010, Stein 2012, Greenwood, Hanson \& Stein 2015). ${ }^{27}$ In the model, banks are endowed with exogenous deposit franchises, and bank-dependent firms exogenously need to raise a portion of their external finance from banks. ${ }^{28}$

This mismatch between banks' assets and liabilities is relevant because future interest rates are uncertain. I take uncertainty regarding future interest rates as exogenous. To fix ideas, I interpret this uncertainty as arising from variation in future consumer discount rates, as in Greenwood et al. (2015). More broadly, monetary policy is a relevant source of variation in nominal interest rates. ${ }^{29} \mathrm{I}$ focus on the US for recent decades: in this period, as inflation has been low and stable, changes in nominal rates closely correspond with changes in real rates. ${ }^{30}$ While I conceptualize firms' output as being only weakly dependent on interest rates, I do include some dependence in the model, capturing the extent to which floating-rate debt provides a natural hedge for firms' asset exposure. This allows the model to capture the effects of variation in firms' associated 'demand' for floating-rate debt.

Following Froot et al. (1993), both banks and firms are effectively risk averse due to financial frictions. Froot et al. (1993) show that, if external finance is costly, constrained firms become effectively risk averse as they cannot fully smooth shocks to internal funds. For simplicity, I capture this hedging motivation with mean-variance preferences for both banks and firms. ${ }^{31}$ Both banks and firms do appear to be at least somewhat risk averse in practice. Despite significant leverage, bank net interest margins

\footnotetext{
${ }^{27}$ Krishnamurthy \& Vissing-Jorgensen (2015) make a related argument: that the financial sector issues short-term bonds because they provide safety, which is in demand.

${ }^{28}$ I take the existence of banks combining monitoring and lending on the asset side and liquidity provision through deposits as exogenous. In practice, investment grade firms sell their bonds to other institutions such as insurance companies and pension funds, which in turn provide insurance services to end consumers through contracts that do not strongly depend on interest rates. It is an ambitious research agenda for future work to understand why monitoring and deposit based liquidity provision are paired together, while arms-length investment and long-term insurance are paired together.

${ }^{29}$ An alternative approach, as in Eggertsson \& Mehrotra (2014), ascribes variation in the interest rate to variation in supply and demand for saving across generations.

${ }^{30}$ If real rates were instead essentially fixed, with inflation driving variation in nominal rates, floating-rate debt would provide a natural economic hedge to firms. In periods of high inflation with high nominal rates, the nominal value of firms' output would also be higher. Internationally, floating-rate debt likely is commonly used as a way to inflation-index contracts.

${ }^{31}$ Froot \& Stein (1998) show that these effectively risk averse preferences can approximately be captured in this manner, where the effective level of risk aversion depends on initial choices regarding capital structure.
} 
have historically been very stable (Flannery 1981, English 2002, English et al. 2013). ${ }^{32}$ Firms also frequently use derivatives with the stated goal of risk management: indeed, as I show in Section 2, bank-dependent firms do attempt to reduce their exposure to interest rates with derivatives.

As collateral requirements make hedging costly, banks can only avoid bearing interest-rate risk by passing some of it on to firms. If hedging were frictionless, mismatch between firms' output and banks' short-term funding would not matter. Firms could borrow at floating rates and fully hedge the exposure, or banks could lend at fixed rates and hedge themselves. I follow a growing literature in arguing that collateral costs make hedging costly (Rampini \& Viswanathan 2010, Rampini et al. 2015, Rampini et al. 2014, Ivashina et al. 2015, Bolton \& Oehmke 2015). Collateral requirements are relevant for banks: Rampini et al. (2015) show that, consistent with collateral costs of hedging, banks reduce their use of derivatives following a negative net worth shock. ${ }^{33}$ I model the opportunity cost of collateral as reduced investment in projects with concave returns, generating convex costs of hedging, following Ivashina et al. (2015).

The model includes a single period, which represents the entire term over which loans are made to firms. Uncertainty regarding interest rates is realized within the period. While the fixed interest rate is known at the beginning of the period, the floating rate is not realized until the end of the period. As I show in Section 2, floating-rate bank lending to firms largely consists of term loans. ${ }^{34}$ The question of why firms and banks negotiate floating-rate term loans instead of short-term debt is itself interesting, but outside the scope of the paper. ${ }^{35}$ The model also incorporates interest-rate derivatives, which will also refer to instruments traded over the life of loans to firms.

Next, I describe the set up of the model. I then use the model to highlight how this combination of factors affects the equilibrium structure of banks' loan and securities portfolios, building up to testable implications regarding bank balance sheets. The key testable implication is that banks with

\footnotetext{
${ }^{32}$ Rajan (2012) notes that in the run up to the Asian financial crisis, domestic banks passed currency risk on to domestic firms, by lending in the same currency they had borrowed in.

${ }^{33}$ Rampini et al. (2015) find that banks halve their use of interest-rate derivatives following a negative net worth shock.

${ }^{34}$ In unreported analysis, I show that maturity of term loans is similar to that of corporate bonds. This likely reflects that firms need to finance long-term projects, producing little cash-flow in the interim. Mian \& Santos (2011) show that the effective maturity of bank loans ranges from 2-4 years, driven by the refinancing behavior of firms with good credit quality.

${ }^{35}$ There is no formal difference between short-term debt rolled over and floating-rate debt in the model.
} 
more floating liabilities should make more floating-rate loans. I also allow banks to adjust their securities portfolios in the model, and show that banks' securities holdings allow me to distinguish the supply-driven view of floating-rate bank lending to firms from the demand-driven view.

\subsection{Banks}

Consider a simple view of bank risk management. Banks make loans, and hold securities, funded by deposit liabilities and internal wealth. Deposit liabilities are short-term, and therefore floating. However, they are also cheap, as pass-through of short-term interest rates is only partial, leading to lower average interest rates than on alternative sources of funding. ${ }^{36}$ This creates the potential for exposure to interest-rate risk: if interest rates rise, causing deposit interest expense to rise, net income will fall if banks hold only fixed-rate assets. Banks' effective risk aversion makes this exposure relevant.

Banks choose the floating fractions of their loan and securities holdings; for simplicity I hold the total size of these portfolios fixed. Banks are exogenously endowed with deposits $D$, a loan portfolio of size $L$, and a securities portfolio of size $S$. For simplicity, the total size of each portfolio is fixed. Internal net worth is the difference $L+S-D$. The future short-term interest rate is $r$, a random variable, with $E[r]=\bar{r}$ and $\operatorname{Var}[r]=\sigma^{2}$. Deposit interest expense is $\alpha r$, where $\alpha<1$ : pass-through on deposits is not complete. Again, this is the sense in which deposits are associated with a money premium. Deposit pass-through, $\alpha$, is also exogenous. Conceptually, I model bank loans as a single asset class with an endogenous characteristic, the floating fraction, determined in equilibrium. Let $f_{L}$ and $f_{S}$ be the floating fraction of loans and securities respectively.

Matching floating-rate liabilities with floating-rate assets involves a tradeoff, as floating-rate assets provide a lower yield. Both loan and security portfolios can be tilted towards being more floating-rate, at the cost of giving up a term premium. ${ }^{37}$ There is a second cost associated with floating-rate loans: firms are also effectively risk averse, and find bearing interest-rate risk costly. A portfolio with more

\footnotetext{
${ }^{36}$ Figure E.1 (Internet Appendix) shows that deposit pass-through in aggregate is partial. This is achieved at least in part by attracting transaction deposits on which no interest is paid.

${ }^{37} \mathrm{~A}$ positive term premium can exist in equilibrium if investors have limited wealth, and are risk averse about duration risk. See, for example, Greenwood, Hanson \& Stein (2010).
} 
floating-rate loans must therefore have lower average interest rates. Let $\mu$ be the loan spread between the rate charged to firms and general interest rates. In Section 3.2, I describe bank-dependent firms' objective function, and derive the equilibrium spread required for bank-dependent firms to continue to borrow the fixed amount, $L$, from banks.

The loan portfolio consists of a fraction $f_{L}$ of floating-rate loans, linked to the short-term interest rate $r$. The interest rate received on the loan portfolio is therefore

$$
\left(1-f_{L}\right)(\bar{r}+\delta)+f_{L} r+\mu^{*}\left(f_{L}\right)
$$

where $\delta>0$ is the term premium. Recall that $E[r]=\bar{r}$. Let the interest rate on short-term securities be $r_{S}$, with the same mean and variance as $r$, and correlation $\rho$ with $r .{ }^{38}$ The interest rate received on the securities portfolio is

$$
\left(1-f_{S}\right)(\bar{r}+\delta)+f_{S} r_{S}
$$

For simplicity, the term premium, $\delta$, is the same for loans and for securities. ${ }^{39}$

Banks can also use interest-rate swaps to manage interest-rate risk, subject to collateral costs. One positive unit of the swap involves making a fixed payment of $\bar{r}+\delta$, where $\delta$ is the term premium, in return for receiving the short-term interest rate $r$. Banks also face collateral costs of using interestrate swaps. Following Ivashina et al. (2015), I model this cost as the opportunity cost of collateral. Hedging requires collateral: for each unit of the derivatives contract, $\bar{q} \in(0,1)$ units of collateral must be posted, reducing investment in outside opportunities. I model the cost of this collateral as $\frac{q}{2} H_{\text {Bank }}^{2}$ where $q=\bar{q}^{2}$. This form for the opportunity cost of collateral can be derived from a production function where loss of output is quadratic from the optimum. ${ }^{40}$

\footnotetext{
${ }^{38}$ This avoids a choice for banks between two assets with effectively identical cash flows but different prices.

${ }^{39} \mathrm{I}$ do not explicitly include monitoring costs or credit risk associated with bank loans in the model. This is one sense in which loan and securities portfolios of exogenous size simplify the model. A more general model including these features could also endogenize banks' asset allocation across these broad asset classes.

${ }^{40}$ Collateral costs in this form can be justified as follow. Banks have concave outside investment opportunities. Absent any use of derivatives, they are able to invest in these outside opportunities at the optimal level. Define the production function as

$$
Z(w)= \begin{cases}\frac{1}{2} \bar{w}^{2}-\frac{1}{2}(\bar{w}-w)^{2} & w \leq \bar{w} \\ \frac{1}{2} \bar{w}^{2} & w>\bar{w}\end{cases}
$$
}


Banks have mean-variance preferences regarding net income. Net income is the sum of interest income on loans and securities, as well as returns on hedging, net of interest expense on deposits and collateral costs of hedging.

$$
\begin{aligned}
N I & =L\left(\left(1-f_{L}\right)(\bar{r}+\delta)+f_{L} r+\mu^{*}\left(f_{L}\right)\right)+S\left(\left(1-f_{S}\right)(\bar{r}+\delta)+f_{L} r_{S}\right) \\
& +H_{\text {Bank }}(r-(\bar{r}+\delta))-D \alpha r-\frac{q}{2} H_{\text {Bank }}^{2}
\end{aligned}
$$

The objective is to maximize

$$
\Omega_{B a n k}=E[N I]-\frac{\gamma}{2} \operatorname{Var}[N I]
$$

where $\gamma$ captures the extent to which banks are effectively risk averse. ${ }^{41}$

I proceed by differentiating this objective function (Equation 4) to obtain first order conditions for $H_{\text {Bank }}, f_{L}$ and $f_{S}$. These first order conditions can be expressed as follows:

$$
\begin{aligned}
H_{\text {Bank }} & =\frac{\gamma \sigma^{2}}{q+\gamma \sigma^{2}}\left(D \alpha-f_{L} L-\rho f_{S} S\right)-\frac{\delta}{q+\gamma \sigma^{2}} \\
f_{L} L & =D \alpha-\rho f_{S} S-H_{\text {Bank }}+\frac{\frac{\partial \mu\left(f_{L}\right)}{\partial f_{L}}-\delta}{\gamma \sigma^{2}} \\
f_{S} S & =\rho\left(D \alpha-f_{L} L-H_{\text {Bank }}\right)-\frac{\delta}{\gamma \sigma^{2}}
\end{aligned}
$$

As Equation 5 shows, collateral requirements $(q>0)$ discourage banks from hedging fully. ${ }^{42}$ Equations 6 and 7 show first order conditions for the floating fractions of loans and securities respectively. Increasing the floating fraction of loans reduces the loan spread. ${ }^{43}$ The expression for securities takes $\rho$, the correlation between the interest rate on securities $r_{S}$ and the general short-term rate $r$, into account. To solve the model, I substitute the expression for $H_{B a n k}$ from Equation 5 back into the objective func-

The optimal level of investment is $\bar{w}$, beyond which there are no further returns to investment. A derivatives position of $H_{\text {Bank }}$ requires $\bar{q} H_{\text {Bank }}$ to be provided as collateral and not invested in outside opportunities. The opportunity cost of doing so is $\frac{q}{2} H_{B a n k}^{2}$, assuming the bank is collateral constrained.

${ }^{41}$ For simplicity, I ignore the role of deposit insurance or any implicit government backing. As Froot \& Stein (1998) note, this effective risk aversion depends on the initial choice of capital structure.

${ }^{42}$ Full hedging requires $H_{\text {Bank }}=D \alpha-f_{L} L-\rho f_{S} S$. A positive term premium $\delta$ also discourages hedging.

${ }^{43}$ See Lemma 1 for an equilibrium expression for $\frac{\partial \mu\left(f_{L}\right)}{\partial f_{L}}$, which depends on the extent to which floating-rate debt is a natural hedge for firms. 
tion. I then derive first order conditions for floating fractions of loans and securities again, this time anticipating subsequent optimal hedging. I discuss the properties of these fractions in equilibrium in Section 3.3. I now turn to the set up for firms.

\subsection{Bank-dependent firms}

In the baseline version of the model, I include only bank-dependent firms. These firms must finance some of their investment with bank debt. Firms have fixed-scale investment, and have output that potentially co-moves with interest rates. They also have mean-variance preferences, as well as access to interest-rate swaps, subject to the same collateral costs as banks. ${ }^{44}$ Again, a positive unit of the swap contract is in the pay-fixed direction.

Bank-dependent firms invest an amount $I$, which must be financed with debt, and produce output $A I+C r$. Potential dependence of output on interest rates, represented by $C$, captures the extent to which floating interest rates are an economic hedge for bank-dependent firms. This will affect the responsiveness of the equilibrium bank loan spread, $\mu$, to a higher floating fraction of lending. Firms borrow an amount $B$ in the form of bank debt, and finance the remainder, $I-B$, with bonds. As noted above, fixed-rate financing is associated with a term premium $\delta$ : the cost of bonds is $\bar{r}+\delta .{ }^{45}$

Bank-dependent firms' net income is

$$
\begin{aligned}
N I_{B D} & =A I+C r-(1+\bar{r}+\delta)(I-B)-\left(1+f_{L} r+\left(1-f_{L}\right)(\bar{r}+\delta)+\mu\right) B \\
& +(r-(\bar{r}+\delta)) H_{B D}-\frac{q}{2} H_{B D}^{2}
\end{aligned}
$$

\footnotetext{
${ }^{44}$ The implicit assumption is that bank-dependent firms hedge with a swap counterparty that is different from their lender. It is more challenging to explain the necessity of collateral requirements from first principles if the lender is also the swap counterparty, as bank-dependent firms typically try to reduce the variability of their interest expense. Firms often do enter into swaps with entities other than their lenders (indeed, for firms with relationships with smaller banks there may be little choice in this regard). Moreover, within large banking organizations, client-facing swap desks often impose their own counterparty exposure limits.

${ }^{45}$ Bond yields typically include an additional credit spread. I exclude this from the model for simplicity.
} 
As firms have mean-variance preferences, the objective is to maximize

$$
\Omega_{B D}=E\left[N I_{B D}\right]-\frac{\gamma}{2} \operatorname{Var}\left[N I_{B D}\right]
$$

For simplicity, I assume that firms have the same effective level of risk aversion as banks.

As with banks, I proceed by first finding the firm's optimal hedging demand, and substituting this into the objective function. Then, I use the first order condition with respect to bank credit to find a credit demand curve from firms' perspective. Using this demand curve, I find the equilibrium loan spread $\mu$ at which firms will demand a fixed quantity, $L$, of bank credit. The thought experiment, therefore, is that banks change the floating fraction of lending without changing the total size of the loan portfolio.

Lemma 1. The equilibrium spread responds to the floating fraction of lending as follows:

$$
\frac{\partial \mu^{*}\left(f_{L}\right)}{\partial f_{L}}=\frac{q\left(\left(C-2 f_{L} L\right) \gamma \sigma^{2}+\delta\right)}{q+\gamma \sigma^{2}}
$$

The proof is omitted. This derivative has a decreasing component, capturing the intuition that banks must accept a lower loan spread to increase the floating fraction. This is attenuated by three factors: first, to the extent that firms' output is cyclical ( $C$ is large), floating-rate loans may be an economic hedge for firms. Second, fixed-rate debt is more expensive due to the term premium $(\delta)$. Third, firms hedge (partially), where the cost of doing so depends on the collateral requirement $q$.

\subsection{Testable predictions}

To summarize the set up, banks fund firms' long-term projects with short-term interest-bearing deposits, creating interest-rate mismatch. Both banks and firms are effectively risk averse due to costly external finance. Anticipating optimal hedging, banks choose the floating fractions of loans and securities to manage interest-rate risk. In the presence of collateral costs of hedging, banks have an incentive to reduce interest-rate risk in part by making floating-rate loans - engaging in operational as well as 
financial hedging. I now lay out the main testable implications generated by this theoretical framework.

A key testable implication of this framework, in which floating-rate liabilities push banks to lend to firms at floating rates, is that banks with more floating liabilities should make more floating-rate loans. Specifically, banks with greater pass-through on deposits should make more floating-rate loans. Proposition 1 summarizes this result. Recall that $\alpha$ represents the degree of pass-through on deposits.

Proposition 1. Banks with more floating-rate liabilities (greater deposit pass-through) should make more floating-rate loans:

$$
\frac{\partial f_{L}^{*}}{\partial \alpha}>0
$$

Proof. See Internet Appendix B.1.

Would showing that banks with more floating liabilities make more floating loans suffice to establish causality in this direction? Is it possible that banks that make more floating loans do so because they have lending relationships with firms that demand floating-rate loans? In terms of the model, such banks might match with firms with more positively cyclical cash flows (more positive $C$ ), for whom floating-rate loans would be a natural hedge.

I show that banks' securities holdings can separate the supply-driven view from firms' demand for floating-rate debt. Proposition 1 shows that, under the supply-driven view, banks with more deposit pass-through should make more floating-rate loans. Such banks should also hold more floating-rate securities to match their liabilities. In contrast, if banks make floating-rate loans because their borrowers demand this interest-rate exposure, they should hold fewer floating-rate securities. While more floating-rate liabilities would reduce interest-rate risk, so would fixed-rate securities. ${ }^{46}$ Proposition 2 summarizes this discussion.

Proposition 2. Banks with more floating-rate liabilities should make more floating-rate loans and hold more floating-rate securities

$$
\frac{\partial f_{L}^{*}}{\partial \alpha}>0, \frac{\partial f_{S}^{*}}{\partial \alpha}>0
$$

\footnotetext{
${ }^{46}$ Deposit pass-through is exogenous here. A more general model could also endogenize deposit pass-through. For example, suppose that retail deposits with very low pass-through are costly to source. Then, banks facing more demand would put less effort into lowering deposit pass-through. This would also generate a negative correlation between deposit pass-through and the floating fraction of banks' securities.
} 
In contrast, banks responding to demand for floating-rate loans from their borrowers should make more floating-rate loans, but hold fewer floating-rate securities

$$
\frac{\partial f_{L}^{*}}{\partial C}>0, \frac{\partial f_{S}^{*}}{\partial C}<0
$$

Proof. See Internet Appendix B.1.

Hence, if banks with more floating liabilities hold more floating securities in addition to making more floating loans, this is consistent with the supply-driven view I argue for, but inconsistent with the idea that firms demand floating-rate loans. Recall that $C$ parametrizes the extent to which firms' cash-flows are positively dependent on interest rates. ${ }^{47}$

The model can address additional features of variation in firms' exposure to interest rates and their use of derivatives with three extensions. First, a price of interest-rate swaps beyond the term premium, determined in equilibrium. Second, the inclusion of firms with better access to capital markets (investment grade firms). For simplicity, they are identical to bank-dependent firms, except that they borrow only with fixed-rate corporate bonds. A positive equilibrium price of swaps induces investment grade firms to bear some interest-rate risk with swaps. Third, to close the model, a set of institutions that bears residual interest-rate risk (to fix ideas, hedge funds), which are risk-neutral, but also face collateral costs of using derivatives. The price of swaps is determined in equilibrium to clear the market.

In the Internet Appendix, I show that this fuller version of the model qualitatively matches the relative levels of interest rate risk that bank-dependent and investment grade firms bear, including the use of derivatives that I document in Section 2. ${ }^{48}$ Collateral costs of hedging prevent all institutions from using derivatives to fully arrive at the desired position. Bank-dependent firms hedge only partially, while investment grade firms actually take on some interest-rate risk with derivatives. Even though both types of firms use derivatives, the convexity of collateral costs of hedging mean that firms do not equate their levels of exposure. The main results, Propositions 1 and 2, continue to hold.

\footnotetext{
${ }^{47}$ The correlation between the floating fractions of loans and securities is informative about the relative importance of cross-sectional variation in supply and demand (see Internet Appendix B.2).

${ }^{48}$ See Internet Appendix B.3.
} 


\section{Empirics: main results}

This section presents the main empirical results of this paper. The evidence supports the supply-driven view of floating-rate bank lending to firms: banks with more floating liabilities make more floating-rate loans. These banks also hold more floating-rate securities, and quote lower prices for adjustable-rate mortgages relative to fixed-rate mortgages, ruling out alternative explanations based on firms' demand for floating-rate debt. I present three types of further evidence of these empirical relationships: first, evidence using deposit competition as an instrument for the interest-rate exposure of bank liabilities, second, time series evidence, and third, historical evidence from periods when deposits were largely non-interest-bearing. ${ }^{49}$

I construct measures of the interest-rate exposure of bank assets and liabilities using bank regulatory data. I measure the extent to which assets are floating with the fraction of assets that are floating. This approach is simpler than estimating duration or maturity weighting, as the maturity and repricing distribution of assets is reported directly. ${ }^{50}$ The literature on bank risk management has also considered return attribution and regressions on short-term interest rates (Flannery 1981, Flannery \& James 1984, English 2002, English et al. 2013). I use this latter approach to measure deposit pass-through, using co-movement of deposit rates with the federal funds rate (in changes) at the bank level. ${ }^{51,52}$

\subsection{Tests of primary hypotheses}

In this subsection, I present my main results: tests of the hypotheses from Section 3. Consistent with Proposition 1, I show that banks with greater interest rate pass-through on deposits make more floatingrate loans. These banks also hold more floating-rate (short-term) securities. As Proposition 2 shows,

\footnotetext{
${ }^{49}$ As bank loans are often prepayable, firms might prefer floating-rate loans to the extent that stable market value facilitates repayment at par. Second, revolving loans and term loans are typically part of the same contractual agreement. It is possible that, at least initially, term loans were floating rate because they were governed by the same agreements as revolving loans.

${ }^{50}$ I find consistent results using this approach on the liability side as well, as in Rampini et al. (2015) and Landier, Sraer \& Thesmar (2015), using regulatory data at the bank holding company level (see Section 4.3).

${ }^{51}$ The literature on deposit pass-through has also used panel regressions and structural partial adjustment models (Samuelson 1945, Berger \& Hannan 1989, Neumark \& Sharpe 1992, Drechsler et al. 2014).

${ }^{52}$ Figure E.1 (Internet Appendix) uses aggregate data to show that deposit interest expense broadly co-moves with shortterm interest rates, with partial pass though. Banks' interest expense on deposits does fluctuate with general interest rates, though pass-through is not complete.
} 
the evidence regarding securities is consistent with the supply-driven view that bank liabilities drive floating-rate lending to firms, but inconsistent with the idea that firms demand floating-rate loans. I also show that banks with more pass through quote lower interest rates for adjustable-rate mortgages relative to fixed-rate mortgages. The combination of higher quantities of floating-rate loans and lower relative prices for them points to supply.

I begin with commercial bank level call report data, as it provides the most disaggregated information on the interest-rate exposure of bank assets. Table 5 shows summary statistics for the sample, which consists of almost 60,000 bank-quarters for about 1,500 banks (I aggregate the data to the parent bank holding company level). ${ }^{53}$ I define the floating fraction of loans and securities as the fraction of loans and securities with remaining maturity or repricing frequency of less than three months, capturing short-term as well as contractually floating-rate assets. I also define similar fractions for loans and, separately, securities not backed by standardized mortgages on single family residences. ${ }^{54}$ These fractions are in percentage points. On average, about 30\% of banks' non-residential loans are floating-rate, and about $10 \%$ of non-residential securities are floating-rate. Floating-rate securities are likely to primarily be short-term securities. ${ }^{55}$

Call report data also allows me to construct a bank level estimate of deposit pass-through using the sensitivity of interest expense on deposits to the federal funds rate. I define an implied deposit interest rate by scaling interest expense on deposits by all deposits, including non-interest-bearing deposits. Subsequently, I estimate deposit pass-through at the bank level by regressing changes in the implied deposit rate on changes in the federal funds rate, using data for 2001Q1-2008Q4. ${ }^{56}$ On average, deposit

\footnotetext{
${ }^{53}$ After the filters I apply, discussed in detail in Internet Appendix C.3, in 2014Q4 the sample covers about $80 \%$ of total commercial bank assets.

${ }^{54}$ Loans and securities make up the majority of commercial bank balance sheets. They comprise about $70 \%$ of commercial bank assets (based on aggregate data as of 2014Q4, compiled by SNL). Loans and securities not backed by standardized housing collateral comprise $40 \%$ and $10 \%$ of bank assets respectively.

${ }^{55}$ This average floating-fraction of non-residential securities may seem low. The largest banks, which have more deposit pass-through, do hold more floating-rate securities. Floating-rate non-residential securities largely consist of short-term government or agency issued debt. Relative to floating-rate bank loans, short-term government bonds provide relatively little yield. If current period yield is particularly important for banks, as in Hanson \& Stein (2015), this might push them away from holding floating-rate securities.

${ }^{56}$ I restrict estimation of pass-through to the period before interest rates were constrained by the zero lower bound. Table E.1 (Internet Appendix) shows that my results are robust to estimating pass-through over the full sample (extending to 2014Q4). It also shows that they are robust to estimating sensitivity to LIBOR instead of the effective federal funds rate.
} 
pass-through is about 30\%: for each percentage point increase in the federal funds rate, deposit interest rates rise by about 30 basis points. I also estimate deposit competition, at the county level, in a manner similar to Drechsler et al. (2014). ${ }^{57}$ Deposits are an important part of bank capital structure: $90 \%$ of bank liabilities, on average, are deposits. ${ }^{58}$

Turning to the results, I first show that banks with more deposit pass-through make more floatingrate loans. Panel A of Table 6 shows regressions of the floating fraction of loans and securities, and of non-residential loans, on deposit pass-through. The regressions collapse the sample to means at the bank level to focus on cross-sectional variation. ${ }^{59}$ They show that both measures are strongly positively related with deposit pass-through. As Proposition 1 shows, this is consistent with my argument that banks match the interest-rate exposure of their assets to the exposure of their liabilities. When deposit pass-through rises by one percentage point, these floating fractions rise by about half a percentage point. A one standard deviation increase in deposit pass-through is associated with a four to five percentage point increase in these floating fractions, or about a quarter of a standard deviation.

Banks achieve this asset-liability matching by adjusting loans both within and across asset classes. Panel A also shows regressions including controls for the fraction of lending related to C\&I lending, consumer lending, and (primarily residential) real-estate related lending. ${ }^{60}$ As these controls are available in detail only for quarters since 2009Q2, I first repeat the earlier regressions for the restricted sample. ${ }^{61}$ The relationship is still strong, although the magnitude is somewhat reduced. Finally, I show regressions including asset mix controls. The relationship continues to be present, though the magnitude drops further, showing that banks adjust their portfolios both within and across asset classes.

Importantly, banks with more pass though also hold more floating-rate securities, establishing that bank liabilities drive banks' floating-rate lending to firms, not borrowers' demand for interest-rate exposure. Panel B of Table 6 looks at the relationship of deposit pass-through and the floating fraction of loans with the floating fraction of securities. In the cross section, the floating fraction of non-residential

\footnotetext{
${ }^{57}$ See Internet Appendix C.3 for more details on the data.

${ }^{58}$ This is an equal weighted average: an asset weighted average is closer to $60 \%$.

${ }^{59}$ I estimate deposit pass-through at the bank level here. See Section 4.3 for results pertaining to time series variation.

${ }^{60}$ See Internet Appendix C.3 for more details on the controls.

${ }^{61}$ Prior to 2009Q2, RMBS and CMBS were not separated, and structured C\&I loans were not reported separately.
} 
securities is positively related with deposit pass-through. The floating fractions of loans and securities are also positively correlated. As Proposition 2 shows, these patterns are consistent with the supplydriven view that floating-rate bank liabilities push banks to lend to firms at floating rates. However, they are inconsistent with the idea that firms demand floating-rate loans: then, the floating fraction of securities would move in the opposite direction to bank liabilities and loans. ${ }^{62}$

I also show that larger banks have greater deposit pass-through and hold more floating-rate loans and securities, suggesting that bank size is one source of variation in the interest-rate exposure of bank liabilities. ${ }^{63}$ I define large banks as the largest $5 \%$ of banks by assets in each quarter. Table 5 shows summary statistics for banks separated by size in this manner. Large banks have greater deposit pass-through. By all measures of floating-rate assets, including securities, large banks also have more floating-rate assets. I discuss the relationship between bank size and deposit pass-through in more detail in Section 4.2.

While most of the analysis I present relates to the floating fractions of banks' assets (quantities), I also present evidence supporting the supply-driven view based on mortgage interest rates (prices). In addition to making floating-rate loans to firms, holding floating-rate securities and using derivatives, making adjustable-rate mortgage loans is another margin of adjustment for banks. ${ }^{64}$ I find that banks with more deposit pass-through offer fixed-rate mortgages (FRMs) at a higher interest rate relative to adjustable-rate mortgages (ARMs). I use branch level interest rates on FRMs and hybrid ARMs, offered as of the final Friday of 2014. I aggregate these to the bank level, weighting by branch deposits. The data, collected and provided by SNL, pertains to jumbo mortgages, which are more likely to be retained on balance sheet. ${ }^{65}$ Table 7 shows the results. In terms of magnitudes, a one standard deviation move in deposit pass-through leads to FRM-ARM spreads that are about 7-8 basis points larger (compared

\footnotetext{
${ }^{62} \mathrm{My}$ results show that cross-sectional variation in supply is more important for explaining variation in equilibrium outcomes than variation in demand. Internet Appendix B.2 presents a framework to think about the relative importance of supply and demand.

${ }^{63}$ Larger banks also have more non-deposit sources of funding (repo, federal funds, wholesale funding) which have much higher interest-rate pass-through than deposits.

${ }^{64}$ Banks do make floating-rate loans beyond loans to firms. Commercial banks hold about \$3.5TN in floating-rate loans in aggregate, and about \$1.6TN in C\&I loans (based on aggregate data as of 2014Q4).

${ }^{65}$ See Internet Appendix C.3 for more details on the data.
} 
to a standard deviation of around 70 basis points). ${ }^{66}$ Variation in mortgage rates therefore points to the supply-driven view: in the cross-section, banks with more floating-rate liabilities hold more floatingrate loans, and charge a lower price for them (relative to fixed-rate loans). ${ }^{67}$

The evidence is therefore consistent with the main hypotheses put forth in Section 3. Variation in three quite different parts of bank balance sheets (loans to firms, mortgages, and securities) points to the supply-driven view of floating-rate bank lending to firms. The rest of this section provides additional evidence, beginning with deposit competition as an instrument for pass-through.

\subsection{Deposit pass-through, competition and size}

I show that deposit pass-through is partly driven by geographic variation in deposit competition, and continue to find my main results using competition as an instrument for deposit pass-through. The impact of deposit competition on deposit pass-through also helps address concerns that the interest-rate exposure of bank liabilities is chosen to match the characteristics of banks' assets rather than dictated by external forces.

As banks are likely to try to minimize deposit interest expense, the idea that banks increase pass through on deposits to reduce mismatch with assets is somewhat implausible. The results so far strongly suggest that banks match the floating mix of their assets to match the nature of their deposit franchise. Results regarding the floating fraction of securities and FRM-ARM spreads are helpful in cutting against the idea that some banks' borrowers demand floating-rate loans, and banks respond by increasing pass through on deposits. Such an explanation would be implausible regardless: if a bank had too many borrowers demanding floating-rate lending, it could hold more long-term, fixed-rate securities. By doing so, it would benefit from the term premium, instead of having to pay more interest on its deposits. Equally, if a bank could reduce pass through on deposits, it would already have done so.

\footnotetext{
${ }^{66}$ The comparatively small magnitude is consistent with the literature: banks might also use non-price mechanisms (differences in quantity or rationing) to affect their asset mix. For example, Foà et al. (2015) emphasize that pricing does not explain all of the variation in quantities they document.

${ }^{67}$ As discussed in Section 3, I model loans to firms as a single asset class, where the floating fraction is a characteristic that affects the equilibrium price. A more general model could separate fixed-rate and floating-rate loans, generating a theoretical counterpart to the variation in FRM-ARM spreads here.
} 
To emphasize this interpretation, I show that competition and bank size are two sources of variation in deposit pass-through. I then recover my main results using competition as an instrument for deposit pass-through. Following Drechsler et al. (2014), I measure competition at the bank level as a deposit-weighted average of county-level Herfindahl Indices of deposit concentration. ${ }^{68}$ Panel A of Table 8 shows cross-sectional regressions (with collapsed samples) of deposit pass-through on bank competition, and on competition and bank size. Banks operating in counties with a Herfindahl Index (HHI) higher by 0.1 (one standard deviation) have deposit pass-through lower by one percentage point. HHI is higher in counties with more deposit concentration, where the market for bank deposits is less competitive. Bigger banks have more deposit pass-through.

My results regarding the floating fractions of loans and securities also hold when I use competition as an instrument for deposit pass-through. Panel B shows regressions of the floating fraction of bank assets on deposit pass-through, using competition as an instrument for pass-through. The outcome variables are the floating fractions of loans and securities, non-residential loans, and non-residential securities. Panel B first shows OLS specifications, repeated from Table 6. It then repeats the first stage from Panel A, reporting the $F$-statistic to show that the first stage is statistically strong. Finally, I show 2SLS versions of these regressions. All regressions show a positive relationship, though the magnitude is somewhat stronger than that from OLS regressions. That this applies to securities as well helps argue against concerns that competition is related to loan opportunities. ${ }^{69}$ In unreported regressions, I show that the component of bank liabilities explained by variation in competition also helps explain the extent to which banks with higher pass through quote higher FRM-ARM spreads. ${ }^{70}$

These results help address concerns that deposit pass-through is a fully endogenous variable, chosen primarily to match the characteristics of banks' assets. Contrary to the view that the composition of banks' liabilities shifts to match the characteristics of banks' assets, I argue that banks match the interest-rate exposure of their assets with that of their liabilities. I take the structure of bank liabilities

\footnotetext{
${ }^{68}$ See Internet Appendix C.3 for more details on the data.

${ }^{69} \mathrm{IV}$ regressions might lead to bigger magnitudes if I estimate deposit pass-through with error. If deposit competition helps isolate variation in pass-through, instrumental variable regressions might reduce attenuation bias.

${ }^{70}$ While the results so far apply to banks' loans in aggregate, I show that they apply to C\&I lending in particular. See Table E.2 (Internet Appendix).
} 
as a largely exogenous variable. Indeed, as noted in Section 3, assume that deposit pass-through is exogenous in the model. The importance of external forces like deposit competition supports this approach. I provide additional supporting evidence based on the response of the structure of banks' deposits to variation in interest-rate conditions in Section 4.3.

\subsection{Time series analysis}

In this subsection, I analyze the relationship between deposit pass-through and bank assets in the time series. I find evidence that within-bank variation in deposit pass-through also helps explain variation in banks' asset interest-rate exposure, using bank holding company level data. I also show the crosssectional relationships presented thus far hold over a longer time period. Finally, I show that banks' liabilities do not seem to adjust to match the structure of bank assets in the time series.

To explore the relationship between deposit pass-through and bank assets in the time series, I turn to bank holding company level data (from form FR-Y9C). While this data provides less detailed information on bank assets, consistent time series can be constructed for a longer sample period (this data is available for 1986Q3-2014Q4). I aggregate this data pro-forma based on present ownership, adjusting for mergers. I restrict the sample to holding companies that meet the requirements for quarterly reporting. The sample consists of about 80,000 bank quarters for close to 2,000 banks. ${ }^{71}$

While a longer time series is available for bank holding company data, floating fractions within categories of assets are not directly reported, and have to be estimated. Here, I define the floating fraction as the fraction of assets with remaining maturity or repricing frequency less than one year. For the entire balance sheet, this information is reported directly. I construct estimates of the floating fraction of loans and securities, and of loans only, by progressively adjusting for federal funds and repo assets, and floating securities. Due to the longer time series, here I am able to estimate a time series of deposit pass-through for each bank. I do so using lagged data for 8-20 quarters, as available. Table 9 shows similar summary statistics to the call report sample (Table 5). It shows again that larger banks have greater deposit pass-through and more floating-rate assets.

\footnotetext{
${ }^{71}$ See Internet Appendix C.4 for more details regarding the data.
} 
I find the cross sectional relationship between deposit pass-through and floating-rate assets in this longer panel, as well as some evidence of a time series relationship. Table 10 looks at the relationship between deposit pass-through and floating assets for this sample. Panel A shows regressions of the three measures of floating assets on deposit pass-through. The first three regressions include only quarter fixed effects. I double cluster standard errors by quarter and bank here. These regressions show that the floating fraction of banks' assets is positively related with deposit pass-through in a sample going back to the late 1980s. Panel A also shows regressions including both quarter and bank fixed effects. While much of the relationship is in the cross section, with this second set of regressions, I do find evidence that within-bank variation in deposit pass-through also helps explain the interest-rate exposure of bank assets. ${ }^{72}$ In the Internet Appendix, I also show that the time series response of banks' liabilities to market conditions is not consistent with the idea that banks adjust their liabilities to match shifts in their assets. ${ }^{73}$

In unreported analysis, I find similar results using the floating fraction of liabilities as the extent to which bank liabilities are floating. I use deposit pass-through as my main measure of the extent to which bank liabilities are floating rate. This directly measures the extent to which deposits are sticky and hence the extent to which bank liabilities are actually floating. It is also possible to construct measures of the floating fraction of bank liabilities (similar to the manner in which I construct the floating fraction of assets). This measure provides a different way to exploit time series variation in the extent to which banks' liabilities are floating. In unreported analysis, I find similar results to those in Panel A of Table 10 using this alternative measure on the liability side. As might be expected, the results are stronger in the time series with this alternative measure.

\footnotetext{
${ }^{72}$ Panel B of Table 10 looks at the relationship between deposit pass-through and bank size in this sample.

${ }^{73}$ Table E.3 (Internet Appendix) shows that when term spreads are high, banks tend to have a smaller fraction of deposits maturing or repricing in less than one year. To match changes in asset composition, bank liabilities would need to co-move with term spreads in the opposite direction: when term spreads are high, mortgages are much more likely to be made at floating rates (Koijen, Van Hemert \& Van Nieuwerburgh 2009).
} 


\subsection{Historical analysis}

I argue that banks' floating-rate liabilities, i.e. short-term, interest-bearing deposits, drive floating-rate bank lending to firms. While this does describe the structure of bank liabilities over the past forty years, bank liabilities have not always been floating. Prior to about 1970, deposits were effectively fixed-rate liabilities, as they were largely non-interest-bearing. In this period realized interest rates on loans were also much less sensitive to short-term interest rates, supporting the supply-driven view that banks' liabilities drive the interest-rate exposure of their lending.

I use the FDIC's Historical Statistics on Banking to show that, historically, deposits were largely non-interest-bearing and loan rates were less sensitive to short-term rates. ${ }^{74}$ Before about 1970, bank liabilities were largely non-interest-bearing demand deposits. ${ }^{75}$ I show that during this period, interest rates on loans did not co-move strongly with short-term rates. While loans were likely extended at floating rates in contractual terms, perhaps during this period banks did not frequently adjust the rates they charged, effectively making the loans fixed rate. ${ }^{76}$ This provides further evidence that the structure of bank liabilities is important for the interest-rate exposure banks pass on to borrowers.

Prior to 1970 , when bank liabilities were mostly non interest-bearing and effectively fixed rate, floating-rate lending, not fixed-rate lending, would have been risky for banks. As data is not available on the floating fraction of lending for this period, I use sensitivity of interest income on loans to shortterm interest rates to assess the extent to which loans were floating rate. I infer average realized interest rates on bank loans on an annual level by dividing interest income on loans and leases by net outstanding loans and leases. ${ }^{77}$ Interest-bearing deposits were subject to (binding) rate ceilings below market rates beginning in 1966. After June 1970, at least some types of time deposits in excess of $\$ 100,000$ were exempt from Regulation Q ceilings on interest rates (Gilbert 1986). ${ }^{78}$ There is substantially more

\footnotetext{
${ }^{74}$ The FDIC's HSOB go back to 1934. Internet Appendix C.5 describes the data and definitions of variables.

${ }^{75}$ The shift in composition from non-interest bearing to interest-bearing was driven partly by a shift in the composition of deposits from demand deposits to time and saving deposits. See Internet Appendix C.5.

${ }^{76}$ This can happen when loans make reference to a benchmark rate set by the bank, such as a prime rate. In contrast, when the benchmark is something like LIBOR, loan rates largely move with market conditions, unless the contract includes a floor (as has become common post-crisis).

${ }^{77}$ Figure E.3 (Internet Appendix) shows this inferred interest rate. It also shows a similarly inferred deposit rate for comparison. The results are very similar if I scale interest income by gross loans and leases instead.

${ }^{78}$ One of the roles of money market mutual funds was to pool smaller deposits into larger amounts above the limit. Also
} 
volatility in both deposit rates and loan rates after about $1970 .^{79}$

Having constructed a time series of realized interest rates on loans, I assess how sensitive these loan rates were to short-term interest rates. If loans are made at floating rates, realized loan rates should strongly co-move with short-term interest rates. In contrast, if loans are made at fixed rates, this should not be the case. ${ }^{80}$ Denote the inferred loan rate by $y_{t}$, and the short-term interest rate by $r_{t}$. I use the yield on three month T-Bills (from the Federal Reserve) as a proxy for the short-term rate. I regress changes in loan rates on changes in short-term rates and compare the results for different periods.

$$
\Delta y_{t}=\alpha+\beta \Delta r_{t}+\rho \Delta y_{t-1}
$$

I include an autoregressive term to allow loan yields to shift slowly.

Interest rates on loans were much less sensitive to short-term rates prior to 1970, suggesting that loans were effectively made at fixed rates in this period. Table 11 shows the results of regressions following Equation 14 in different periods. Prior to 1970, loan rates were not very responsive to shortterm interest rates: they rose only about 20 basis points for a 100 basis point increase in short-term rates. The long term response, $\beta /(1-\rho)$, was about 40 basis points. The $R^{2}$ from the regression is small: only $27 \%$. In contrast, after 1970 , loan rates co-moved more strongly with short-term interest rates. They rose almost 50 basis points for a 100 basis point increase in short-term rates. The long term response was almost 70 basis points. ${ }^{81}$ The $R^{2}$ from the regression also rises substantially, to $79 \%$. Simulations show that these results imply that only about $10 \%$ of loans were floating-rate before 1970 , while around $25-40 \%$ were floating-rate subsequently. Consistent with my overall argument, therefore, these results suggest that early in the sample period when bank liabilities were predominantly fixed rate, bank loans were also effectively made at fixed rates.

In summary, the evidence supports the supply-driven view that bank liabilities drive floating-rate

see Friedman (1986) for more on this period.

${ }^{79}$ See Figure E.3 (Internet Appendix).

${ }^{80}$ If bank loans were always short term, this distinction would not be meaningful. In the period for which I have Capital IQ data, I show in unreported analysis that the bank loans are typically extended at five year terms.

${ }^{81}$ I choose the year 1970 as the cutoff because this is approximately when the majority of bank liabilities became interest bearing. The results are similar using any year from 1965-1975. 
bank lending to firms. Consistent with Proposition 1, banks with more floating-rate liabilities make more floating-rate loans. They also hold more floating-rate securities. As Proposition 2 shows, this allows me to rule out the idea that firms demand floating-rate loans. These results hold when I instrument for pass through with deposit competition. I also show that banks with more floating liabilities quote lower interest rates for ARMs, relative to FRMs. In addition to the historical evidence presented in this subsection, I also find some evidence of time-series versions of these relationships.

\section{Implications for transmission of monetary policy}

In this section I draw out the implications of floating-rate bank lending for monetary policy. I interpret the effect of floating-rate bank lending as a component of the Bernanke \& Gertler (1995) balancesheet channel of transmission of monetary policy. I also use the sensitivity of investment to noninterest expense related components of cash flow to impute the size of the effect of investment for bank-dependent firms. Finally, I show that this imputed effect can account for a significant portion of the greater relative interest rate sensitivity of bank-dependent firms' investment.

Banks play a role in the transmission of monetary policy to firms by lending to them at floating rates; this is distinct from the usual bank lending channel, and is an important component of the Bernanke \& Gertler (1995) balance-sheet channel. Under the traditional bank lending channel, firms are adversely affected by tighter monetary policy because less new bank lending is available (Kashyap \& Stein 1994, Kashyap \& Stein 2000, Peek \& Rosengren 2013). ${ }^{82}$ I emphasize that bank-dependent firms are more directly affected by changes in interest rates: as bank lending is largely floating rate, the cost of these firms' existing debt responds to changes in interest rates. This is a version of the Bernanke \& Gertler (1995) balance-sheet channel, in which firms' financial health deteriorates as interest rates rise, both because interest expense rises and because cash flows fall as aggregate demand falls. Bernanke \& Gertler (1995) focus on the importance of short-term debt (commercial paper); here

\footnotetext{
${ }^{82}$ This channel is based on changes in reserve requirements, which may be less relevant in the current environment of significant excess reserves. Drechsler et al. (2014) suggest an alternative channel linking new bank lending to interest rates, based on how banks exercise their market power.
} 
I show the relevance of floating-rate debt. ${ }^{83}$

Bank-dependent firms' financial condition, as measured by interest coverage ratios, is more sensitive to interest rates than that of firms with better access to capital markets. To show this, I use a sample containing capital structure and balance sheet data, as before, as well as data on total interest expense. I calculate firms' interest coverage ratios, defined as the ratio of interest expense to operating income before depreciation. I identify bank-dependent firms as firms with a high average fraction of bank debt, within industry. These firms' interest coverage ratios are more sensitive to short-term interest rates. ${ }^{84}$

Floating-rate bank lending is a significant contributor to this greater sensitivity. In this sample, bank-dependent firms obtain two thirds of their debt finance from banks, largely at floating rates, while firms with better access to capital markets obtain only one sixth of their debt from banks. As discussed in Section 2, firms only partially hedge away these differences: within the derivatives data subsample, bank-dependent firms have twice as much floating-rate debt as a fraction of assets after taking hedging into account. ${ }^{85}$ Bank-dependent firms have similar aggregate cash flows as firms with better access to capital markets. Bank-dependent firms are present in every industry; indeed, I identify bank-dependent firms based on the fraction of bank debt within industry. As shown in Section 2, bank-dependent firms do not have more cyclical cash flows to offset floating-rate bank debt. Both types of firms had similar cash flows over the recent business cycle and crisis. ${ }^{86}$ While bank-dependent firms did experience a sharper response during the financial crisis, their cash flows are not more sensitive to interest rates.

To the extent that bank-dependent firms are more financially constrained at times when central banks are likely to lower interest rates, floating-rate bank loans might provide a natural hedge. Bankdependent firms do not have more cyclical cash-flows, and do partially hedge their exposure to rates. Evidence from the cross-section of bank-balance sheets, presented in Section 4, shows that most variation in floating-rate debt is driven by variation in bank credit supply. However, it may be the case that

\footnotetext{
${ }^{83}$ Monetary policy also affects firms through the classic discount rate channel (Keynes 1936).

${ }^{84}$ See Figure E.4 (Internet Appendix).

${ }^{85}$ Panel A of Figure E.5 (Internet Appendix) shows that bank-dependent firms' realized interest rates are more sensitive to interest rates. The recent prominence of interest-rate floors means that firms will be less exposed to initial increases in short-term interest rates going forward. Consistent with my argument, Cohen, Lee \& Stebunovs (2016) document that floors are more prominent for loans made by syndicates with a higher share of non-bank lenders.

${ }^{86}$ See Panel B of Figure E.5 (Internet Appendix).
} 
bank-dependent firms tend to be more financially constrained in poor macroeconomic environments, which is when central banks are likely to lower rates. Then, floating-rate bank loans allow the benefits of looser monetary policy to flow to bank-dependent firms.

As interest rates vary, bank-dependent firms face cash-flow shocks through changes in interest expense on floating-rate debt. To quantify the effect these shocks have on investment, I use the methodology of the investment cash-flow sensitivity literature (Fazzari et al. 1988, Baker, Stein \& Wurgler 2003, Greenwood 2003). This literature argues that investment responds to cash-flow shocks of any kind, as external finance is costly. I produce similar estimates using variation in cash flow unrelated to interest expense and use them to impute the effect of cash-flow shocks from floating-rate debt on investment. In the Internet Appendix, I show that this channel can account for a significant portion of the greater interest-rate sensitivity of bank-dependent firms' investment. ${ }^{87}$

\section{Conclusion}

Bank lending is in large part funded with floating-rate deposits. As hedging is costly, banks avoid mismatch with the interest-rate exposure of their liabilities, in part, by making floating-rate loans to firms. To establish this link between the structure of bank liabilities and the floating-rate nature of bank lending, I examine the cross section of banks. Banks with greater interest rate pass-through on their deposits hold more floating-rate assets: both loans and securities. In the cross section, these floating fractions are positively correlated with each other. I show that if banks were responding to demand for floating-rate debt from firms instead of their own liabilities, this correlation would be negative. Moreover, while banks with more deposit pass-through hold more floating-rate loans, they quote lower interest rates for ARMs relative to FRMs. The combination of higher quantities and lower prices points to variation in supply rather than demand. I also present time series and historical evidence supporting the supply-driven view of floating-rate bank lending to firms.

This paper therefore highlights an important consequence of banks' short-term funding: the po-

\footnotetext{
${ }^{87}$ See Internet Appendix D.
} 
tential for interest-rate mismatch. While standard models do analyze maturity mismatch created by short-term funding, they typically do not consider uncertainty in interest rates and interest-rate mismatch. This paper shows that the structure of banks' funding has important implications for the choices banks make about interest-rate risk on the asset side of their balance sheets. More broadly, my results establish an important link between intermediaries' funding structure and the types of contracts used by non-financial firms. My results suggest that tighter regulation of banks' exposure to interest rates might lead banks to pass on more risk to firms, which is particularly relevant given renewed regulatory focus on banks' exposure to rates.

Bank-dependent firms, i.e. poorly rated firms and smaller firms, are more exposed to interest rates than firms with better access to capital markets. While these firms do use interest-rate derivatives to hedge this exposure, they do so only partially. I show that this exposure is a component of the Bernanke \& Gertler (1995) balance-sheet channel of transmission of monetary policy. Banks therefore play a role in the transmission of monetary policy to firms beyond the usual bank lending channel; here the effect is based on existing rather than new bank lending. 


\section{References}

Auclert, A. (2015), 'Monetary policy and the redistribution channel'.

Baker, M., Stein, J. C. \& Wurgler, J. (2003), 'When does the market matter? stock prices and the investment of equity-dependent firms', Quarterly Journal of Economics 118(3), 969-1005.

Becker, B., Bos, M. \& Roszbach, K. (2015), 'Bad times, good credit', Swedish House of Finance Research Paper (15-05).

Begenau, J., Piazzesi, M. \& Schneider, M. (2015), 'Banks’ risk exposures’.

Berger, A. N. \& Hannan, T. H. (1989), 'The price-concentration relationship in banking', Review of Economics and Statistics 71(2), 291-299.

Bernanke, B. S. \& Gertler, M. (1995), 'Inside the black box: The credit channel of monetary policy transmission', Journal of Economic Perspectives 9(4), 27-48.

Bicksler, J. \& Chen, A. H. (1986), 'An economic analysis of interest rate swaps', Journal of Finance 41(3), 645-655.

Bodnar, G. M., Graham, J., Harvey, C. R. \& Marston, R. C. (2011), 'Managing risk management'.

Bolton, P. \& Oehmke, M. (2015), 'Should derivatives be privileged in bankruptcy?', The Journal of Finance 70(6), 2353-2394.

Bretscher, L., Mueller, P., Schmid, L. \& Vedolin, A. (2015), 'Interest rate risk and corporate hedging' .

Calza, A., Monacelli, T. \& Stracca, L. (2013), 'Housing finance and monetary policy', Journal of the European Economic Association 11(s1), 101-122.

Campbell, T. S. \& Kracaw, W. A. (1993), Financial Risk Management: Fixed income and foreign exchange, HarperCollins.

Chernenko, S. \& Faulkender, M. (2011), 'The two sides of derivatives usage: Hedging and speculating with interest rate swaps', Journal of Financial and Quantitative Analysis 46(6), 1727-1754.

Cohen, G., Lee, S. J. \& Stebunovs, V. (2016), 'Limits to monetary policy transmission at the zero lower bound and beyond: Evidence from syndicated leveraged loan markets'.

Colla, P., Ippolito, F. \& Li, K. (2013), 'Debt specialization', Journal of Finance 68(5), 2117-2141.

Di Maggio, M., Kermani, A. \& Ramcharan, R. (2015), 'Monetary policy pass-through: Household consumption and voluntary deleveraging'.

Diamond, D. W. (1984), 'Financial intermediation and delegated monitoring', Review of Economic Studies 51(3), 393-414.

Diamond, D. W. \& Dybvig, P. H. (1983), 'Bank runs, deposit insurance, and liquidity', Journal of Political Economy 91(3), 401-419. 
Drechsler, I., Savov, A. \& Schnabl, P. (2014), 'The deposits channel of monetary policy'.

Eggertsson, G. B. \& Mehrotra, N. R. (2014), A model of secular stagnation, Technical report, National Bureau of Economic Research.

English, W. B. (2002), 'Interest rate risk and bank net interest margins', BIS Quarterly Review 12(02), 67-82.

English, W. B., Van den Heuvel, S. J. \& Zakrajšek, E. (2013), 'Interest rate risk and bank equity valuations'.

Fama, E. F. \& French, K. R. (1997), 'Industry costs of equity', Journal of Financial Economics 43(2), 153-193.

Fazzari, S. M., Hubbard, R. G. \& Petersen, B. C. (1988), 'Financing constraints and corporate investment', Brookings Papers on Economic Activity 1988(1), 141-206.

Flannery, M. J. (1981), 'Market interest rates and commercial bank profitability: An empirical investigation', Journal of Finance 36(5), 1085-1101.

Flannery, M. J. \& James, C. M. (1984), 'The effect of interest rate changes on the common stock returns of financial institutions', Journal of Finance 39(4), 1141-1153.

Foà, G., Gambacorta, L., Guiso, L. \& Mistrulli, P. E. (2015), 'The supply side of housing finance'.

Friedman, B. M. (1986), Money, credit, and interest rates in the business cycle, in 'The American business cycle: Continuity and change', University of Chicago Press, pp. 395-458.

Froot, K. A., Scharfstein, D. S. \& Stein, J. C. (1993), 'Risk management: Coordinating corporate investment and financing policies', Journal of Finance 48(5), 1629-1658.

Froot, K. A. \& Stein, J. C. (1998), 'Risk management, capital budgeting, and capital structure policy for financial institutions: an integrated approach', Journal of Financial Economics 47(1), 55-82.

Gilbert, R. A. (1986), 'Requiem for regulation q: What it did and why it passed away', Federal Reserve Bank of St. Louis Review (February 1986).

Gorton, G. B. (2010), Slapped by the invisible hand: The panic of 2007, Oxford University Press.

Gorton, G. \& Pennacchi, G. (1990), 'Financial intermediaries and liquidity creation', Journal of Finance 45(1), 49-71.

Greenwood, R. (2003), 'Evidence for a debt financing channel in corporate investment'.

Greenwood, R., Hanson, S. G. \& Stein, J. C. (2015), 'A comparative-advantage approach to government debt maturity', Journal of Finance 70(4), 1683-1722.

Greenwood, R., Hanson, S. \& Stein, J. C. (2010), 'A gap-filling theory of corporate debt maturity choice', The Journal of Finance 65(3), 993-1028. 
Guay, W. \& Kothari, S. P. (2003), 'How much do firms hedge with derivatives?', Journal of Financial Economics 70(3), 423-461.

Hanson, S. G., Shleifer, A., Stein, J. C. \& Vishny, R. W. (2014), Banks as patient fixed-income investors, Technical report, National Bureau of Economic Research.

Hanson, S. G. \& Stein, J. C. (2015), 'Monetary policy and long-term real rates', Journal of Financial Economics 115(3), 429-448.

Holmström, B. \& Tirole, J. (1998), 'Private and public supply of liquidity', Journal of Political Economy 106(1), 1-40.

Ippolito, F., Ozdagli, A. K. \& Perez, A. (2015), 'The transmission of monetary policy through bank lending: The floating rate channel'.

Ivashina, V., Scharfstein, D. S. \& Stein, J. C. (2015), 'Dollar funding and the lending behavior of global banks', Quarterly Journal of Economics 130(3), 1241-1281.

Kashyap, A. K., Rajan, R. \& Stein, J. C. (2002), 'Banks as liquidity providers: An explanation for the coexistence of lending and deposit-taking', Journal of Finance 57(1), 33-73.

Kashyap, A. K. \& Stein, J. C. (1994), Monetary policy and bank lending, in 'Monetary policy', The University of Chicago Press, pp. 221-261.

Kashyap, A. K. \& Stein, J. C. (2000), 'What do a million observations on banks say about the transmission of monetary policy?', American Economic Review 90(3), 407-428.

Keynes, J. M. (1936), The general theory of interest, employment and money, London: Macmillan.

Keys, B. J., Piskorski, T., Seru, A. \& Yao, V. (2014), Mortgage rates, household balance sheets, and the real economy, Technical report, National Bureau of Economic Research.

Koijen, R. S., Van Hemert, O. \& Van Nieuwerburgh, S. (2009), 'Mortgage timing', Journal of Financial Economics 93(2), 292-324.

Krishnamurthy, A. \& Vissing-Jorgensen, A. (2015), 'The impact of treasury supply on financial sector lending and stability', Journal of Financial Economics 118(3), 571-600.

Landier, A., Sraer, D. \& Thesmar, D. (2015), 'Banks exposure to interest rate risk and the transmission of monetary policy'.

Mian, A. R. \& Santos, J. A. (2011), 'Liquidity risk, and maturity management over the credit cycle'.

Neumark, D. \& Sharpe, S. A. (1992), 'Market structure and the nature of price rigidity: evidence from the market for consumer deposits', The Quarterly Journal of Economics 107(2), 657-680.

Peek, J. \& Rosengren, E. S. (2013), 'The role of banks in the transmission of monetary policy'.

Rajan, R. (2012), Fault lines, HarperCollins Publishers. 
Rampini, A. A., Sufi, A. \& Viswanathan, S. (2014), 'Dynamic risk management', Journal of Financial Economics 111(2), 271-296.

Rampini, A. A. \& Viswanathan, S. (2010), 'Collateral, risk management, and the distribution of debt capacity', Journal of Finance 65(6), 2293-2322.

Rampini, A. A., Viswanathan, S. \& Vuillemey, G. (2015), 'Risk management in financial institutions'.

Rauh, J. D. \& Sufi, A. (2010), 'Capital structure and debt structure', Review of Financial Studies 23(12), 4242-4280.

Samuelson, P. A. (1945), 'The effect of interest rate increases on the banking system', American Economic Review 35(1), 16-27.

Stein, J. C. (2012), 'Monetary policy as financial stability regulation', Quarterly Journal of Economics 127(1), 57-95.

Stulz, R. (2003), Risk Management and Derivatives, SWC-Finance Series, Thomson/South-Western.

Sufi, A. (2015), 'Out of many, one? household debt, redistribution and monetary policy during the economic slump', Andrew Crockett Memorial Lecture.

Thompson, S. B. (2011), 'Simple formulas for standard errors that cluster by both firm and time', Journal of Financial Economics 99(1), 1-10.

Tirole, J. (2006), The Theory of Corporate Finance, Princeton University Press.

Titman, S. (1992), 'Interest rate swaps and corporate financing choices', Journal of Finance 47(4), 1503-1516.

Tufano, P. (1996), 'Who manages risk? an empirical examination of risk management practices in the gold mining industry', Journal of Finance 51(4), 1097-1137.

Vickery, J. (2005), How and why do small firms manage interest rate risk? evidence from commercial loans, Technical report, Staff Report, Federal Reserve Bank of New York.

Working, E. J. (1927), 'What do statistical" demand curves" show?', The Quarterly Journal of Economics 41(2), 212-235. 


\section{A Tables and Figures}

Table 1: Summary statistics for sample of firms

Notes: The sample combines balance sheet data from Compustat for firms headquartered in the USA, debt capital structure details from Capital IQ and ratings from S\&P. I exclude financial firms and utilities in the Fama \& French (1997) 12 industry classification. The data is annual, and goes from 2003-2013. I require debt reported by Capital IQ and Compustat to be within $10 \%$ of each other, and variable and fixed-rate debt to total to within $10 \%$ of Capital IQ debt, for at least half of the observations at the firm level. I exclude observations where the fraction of floating or bank debt is greater than $110 \%$, or where the debt/assets ratio is greater than $120 \%$. Ratios to debt and assets and cash-flow beta are winsorized at the $1 \%$ level on both sides. See Internet Appendices C.1 and C.2 for more details. Panel A shows summary statistics for the full sample. I also collect data on usage of interest-rate swaps for SEC filings. Panel B shows summary statistics for the sub-sample where this data is available.

Panel A: Full sample

\begin{tabular}{lrrr}
\hline & Median & Mean & Std. Dev. \\
\hline Assets (MM) & 976.0 & $4,567.2$ & $23,936.6$ \\
Floating Fraction & 30.3 & 38.3 & 34.6 \\
Bank Fraction & 36.2 & 42.7 & 37.5 \\
Debt/Assets & 29.5 & 33.1 & 21.6 \\
LTD/Debt & 93.9 & 80.9 & 27.9 \\
CAPX/Assets & 3.4 & 5.8 & 7.0 \\
RD/Assets & 0.0 & 2.1 & 5.2 \\
CF Beta & 0.1 & 0.2 & 3.0 \\
\hline Firm-Years & 13,400 & & \\
Firms & 2,186 & & \\
\hline
\end{tabular}

Panel B: Derivatives sub-sample

\begin{tabular}{lrrr}
\hline & Median & Mean & Std. Dev. \\
\hline Assets (MM) & $1,526.8$ & $4,325.6$ & $10,490.5$ \\
Floating Fraction & 26.9 & 34.9 & 32.2 \\
Bank Fraction & 30.4 & 38.2 & 35.2 \\
Net Pay Fixed & 0.0 & 6.1 & 22.3 \\
Post-Hedge Floating & 22.9 & 28.8 & 31.1 \\
Post-Hedge Floating/Assets & 6.7 & 10.2 & 12.9 \\
\hline Firm-Years & 4,846 & & \\
Firms & 571 & & \\
\hline
\end{tabular}


Figure 1: Debt structure by rating and size

Notes: The data is annual, and goes from 2003-2013. See Internet Appendix C.1 for more details. The figure shows types of debt (revolving loans, term loans, commercial paper and floating-rate bonds) as a fraction of debt (value weighted). Term loans are separated into fixed and floating rate. The remainder of the debt (not shown) is primarily fixed-rate bonds. Panel A shows capital structure by rating. Panel B shows capital structure for firms sorted into size tercile by year.

Panel A: Debt by firm rating

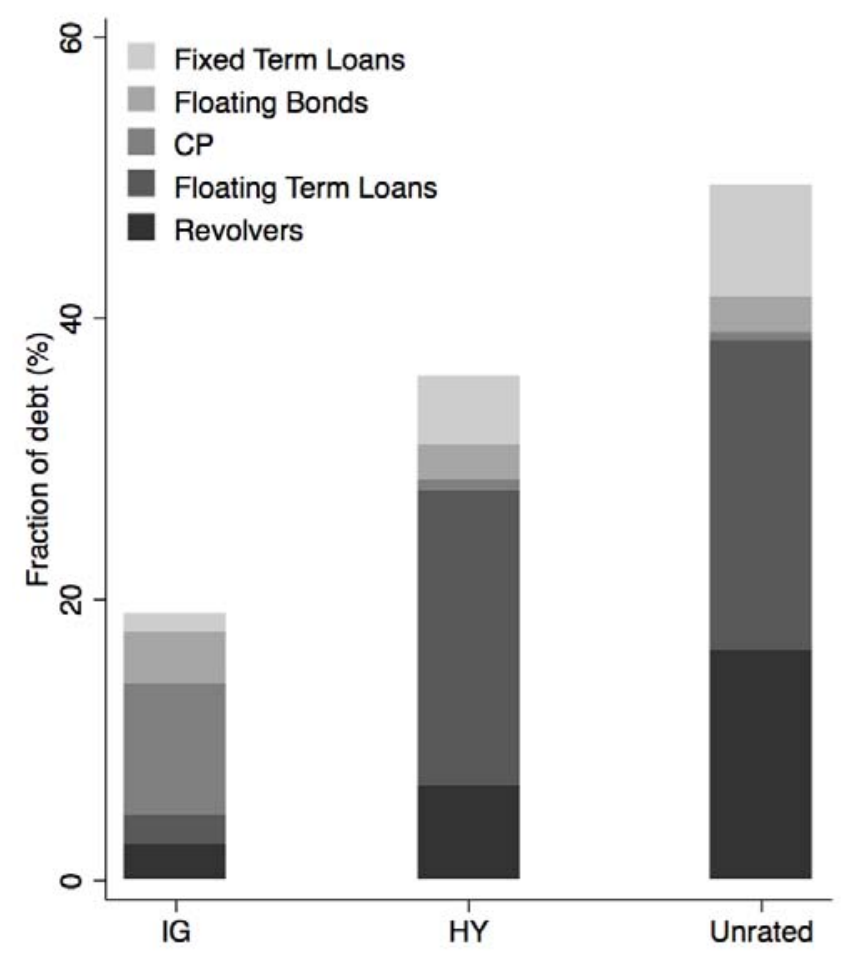

Panel B: Debt by firm size

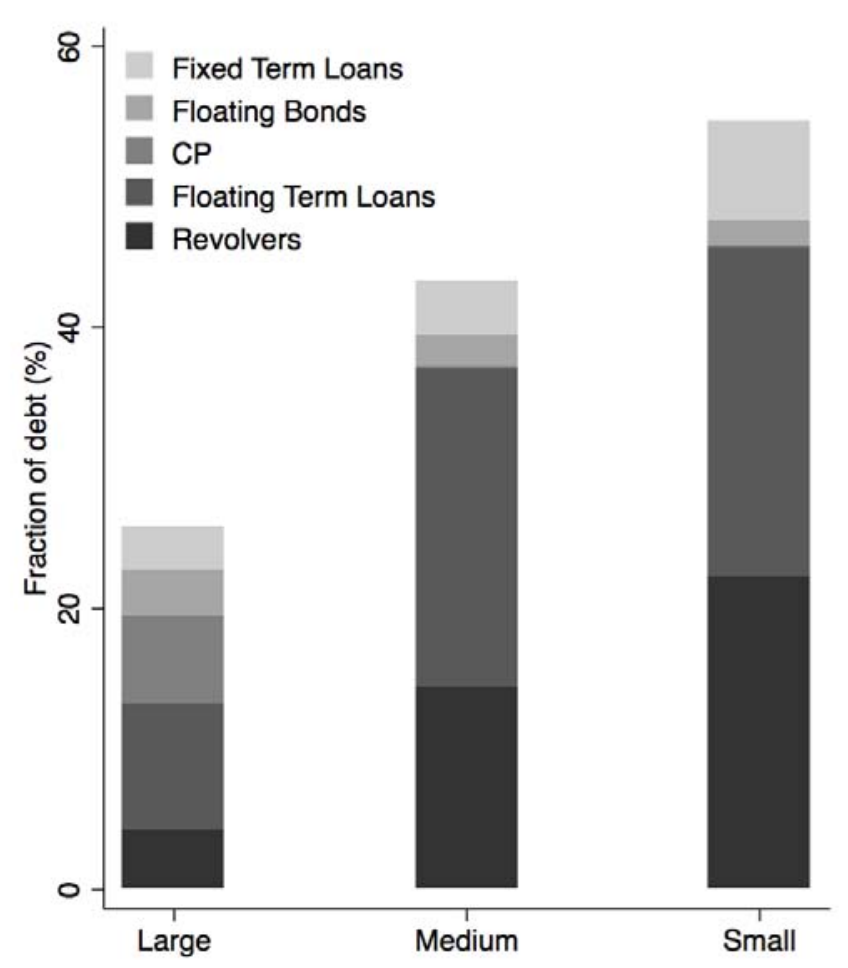


Table 2: Determinants of floating debt

Notes: The data is annual, and goes from 2003-2013. See Internet Appendix C.1 for more details. The outcome variable is the fraction of debt that is floating. Debt rated is a dummy variable for whether the firm has any rating (for long-term debt or short-term debt) in the year. Ratios with assets and debt are defined based on Compustat variables. Cash-flow beta is the regression coefficient of operating income before depreciation on LIBOR. Swap spread is the 5Y swap - Treasury spread, and the term spread is $5 \mathrm{Y}-1 \mathrm{Y}$ treasury yield. Floating debt and bank fraction are in percentage points. $\ln$ (assets), ratios to debt and assets, and cash-flow beta are winsorized at the $1 \%$ level on both sides. These variables and interest rate conditions are normalized to have unit variance. 'Collapsed' specifications collapse the sample to means at the firm level. Specifications with firm fixed effects restrict to firms with at least 5 years of data, with standard errors double clustered by firm and year. $t$-statistics are shown in parentheses to the right.

\begin{tabular}{|c|c|c|c|c|c|c|c|c|}
\hline \multirow[b]{3}{*}{ Bank Fraction } & \multicolumn{4}{|c|}{ Collapsed } & \multicolumn{4}{|c|}{ Firm FE } \\
\hline & \multicolumn{2}{|c|}{ Floating Fraction } & \multicolumn{2}{|c|}{ Floating Fraction } & \multicolumn{2}{|c|}{ Floating Fraction } & \multicolumn{2}{|c|}{ Floating Fraction } \\
\hline & 0.60 & $(46.13)$ & 0.57 & $(38.98)$ & 0.73 & $(42.47)$ & 0.71 & $(39.82)$ \\
\hline Debt rated & & & -4.53 & $(-3.23)$ & & & -3.12 & $(-2.25)$ \\
\hline Debt/Assets & & & 2.21 & $(4.27)$ & & & -0.03 & $(-0.05)$ \\
\hline Intangible/Assets & & & 2.04 & $(3.96)$ & & & 1.16 & $(1.46)$ \\
\hline RD/Assets & & & -0.84 & $(-2.21)$ & & & -0.87 & $(-0.74)$ \\
\hline $\ln$ (Assets) & & & 0.03 & $(0.04)$ & & & 1.68 & $(0.98)$ \\
\hline CAPX/Assets & & & 0.33 & $(0.60)$ & & & 0.51 & (1.16) \\
\hline LTD/Debt & & & -0.84 & $(-1.46)$ & & & -0.71 & $(-1.73)$ \\
\hline CF Beta & & & -0.09 & $(-0.28)$ & & & & \\
\hline Swap Spread & & & & & & & 0.56 & $(2.88)$ \\
\hline Term Spread & & & & & & & -0.32 & $(-1.57)$ \\
\hline SE clustered by & - & & - & & Firm, $Y$ & & Firm, $Y$ & \\
\hline$R^{2}$ & 0.49 & & 0.51 & & 0.74 & & 0.75 & \\
\hline Firm-Years & 13,400 & & 13,400 & & 11,363 & & 11,363 & \\
\hline Firms & 2,186 & & 2,186 & & 1,404 & & 1,404 & \\
\hline
\end{tabular}


Table 3: Risky, small firms bear more interest-rate risk

Notes: The data is annual, and goes from 2003-2013. See Internet Appendix C.1 for more details. The outcome variables are the floating fraction of debt (V/D), the debt/assets ratio (D/A) and floating debt as a fraction of assets (V/A). In Panel A, specifications on the left show firms separated by rating, where the omitted category is investment grade (IG) firms. Specifications on the right show firms separated by size, based on size terciles assigned within fiscal year, where the omitted category is large firms. Panel B shows regressions with the same outcome variables, but restricting the sample to the two ratings closest to the IG/HY cutoff, and including industry and year fixed effects. Standard errors are double clustered by firm and year. $t$-statistics are shown in parentheses.

Panel A: Split by rating and size

\begin{tabular}{|c|c|c|c|c|c|c|}
\hline & \multicolumn{3}{|c|}{ Rating } & \multicolumn{3}{|c|}{ Size } \\
\hline & $\mathrm{V} / \mathrm{D}$ & $\mathrm{D} / \mathrm{A}$ & V/A & $\mathrm{V} / \mathrm{D}$ & $\mathrm{D} / \mathrm{A}$ & V/A \\
\hline Constant & $\begin{array}{r}18.33 \\
(10.52)\end{array}$ & $\begin{array}{r}26.27 \\
(37.09)\end{array}$ & $\begin{array}{r}4.91 \\
(10.47)\end{array}$ & $\begin{array}{r}25.98 \\
(14.22)\end{array}$ & $\begin{array}{r}33.65 \\
(39.56)\end{array}$ & $\begin{array}{r}9.77 \\
(12.10)\end{array}$ \\
\hline High Yield & $\begin{array}{r}14.43 \\
(8.23)\end{array}$ & $\begin{array}{r}19.01 \\
(19.84)\end{array}$ & $\begin{array}{r}10.78 \\
(12.25)\end{array}$ & & & \\
\hline Unrated & $\begin{array}{r}29.74 \\
(20.20)\end{array}$ & $\begin{array}{r}1.67 \\
(1.75)\end{array}$ & $\begin{array}{r}8.87 \\
(20.51)\end{array}$ & & & \\
\hline Medium & & & & $\begin{array}{r}13.07 \\
(10.63)\end{array}$ & $\begin{array}{r}3.23 \\
(3.45)\end{array}$ & $\begin{array}{r}5.03 \\
(8.46)\end{array}$ \\
\hline Small & & & & $\begin{array}{r}23.81 \\
(15.46)\end{array}$ & $\begin{array}{r}-4.91 \\
(-4.82)\end{array}$ & $\begin{array}{r}4.32 \\
(5.58)\end{array}$ \\
\hline SE Clustered By & Firm,Y & Firm,Y & Firm, $Y$ & Firm,Y & Firm,Y & Firm, Y \\
\hline$R^{2}$ & 0.11 & 0.15 & 0.06 & 0.08 & 0.02 & 0.02 \\
\hline Firm-Years & 13,400 & 13,400 & 13,400 & 13,400 & 13,400 & 13,400 \\
\hline Firms & 2,186 & 2,186 & 2,186 & 2,186 & 2,186 & 2,186 \\
\hline
\end{tabular}

Panel B: Restricted to BBB- and BB+firms

\begin{tabular}{lrrr}
\hline & V/D & D/A & V/A \\
\hline BB+ & 7.28 & 3.78 & 3.15 \\
& $(2.79)$ & $(2.45)$ & $(3.35)$ \\
\hline Industry FE & $\mathrm{Y}$ & $\mathrm{Y}$ & $\mathrm{Y}$ \\
Year FE & $\mathrm{Y}$ & $\mathrm{Y}$ & $\mathrm{Y}$ \\
SE Clustered By & Firm,Y & Firm,Y & Firm, Y \\
$R^{2}$ & 0.07 & 0.05 & 0.08 \\
Firm-Years & 1,057 & 1,057 & 1,057 \\
Firms & 273 & 273 & 273 \\
\hline
\end{tabular}


Table 4: Risky, small firms bear more interest-rate risk post-hedging

Notes: The data is annual, and goes from 2003-2013. These regressions are for the derivatives sub-sample. See Internet Appendices C.1 and C.2 for more details. The outcome variables are the floating fraction of debt (V/D), net pay fixed swaps as a fraction of debt (NPF/D), post-hedging floating fraction of debt (V-NPF/D), the debt/assets ratio (D/A) and post-hedging floating debt as a fraction of assets (V-NPF/A). Panel A shows firms separated by rating, where the omitted category is investment grade (IG) firms. Panel B shows firms separated by size, based on size terciles within fiscal year, where the omitted category is large firms. Standard errors are double clustered by firm and year. $t$-statistics are shown in parentheses.

\section{Panel A: Split by rating}

\begin{tabular}{lrrrrr}
\hline & \multicolumn{1}{c}{ V/D } & \multicolumn{1}{c}{ NPF/D } & \multicolumn{1}{c}{ (V-NPF)/D } & \multicolumn{1}{c}{ (V-NPF)/A } \\
\hline Constant & 18.28 & -5.07 & 23.35 & 27.27 & 6.44 \\
& $(10.77)$ & $(-3.43)$ & $(9.70)$ & $(25.53)$ & $(10.32)$ \\
High Yield & 13.95 & 13.74 & 0.21 & 19.94 & 4.95 \\
& $(5.95)$ & $(8.58)$ & $(0.09)$ & $(13.43)$ & $(6.37)$ \\
Unrated & 28.42 & 13.58 & 14.84 & 0.69 & 4.07 \\
& $(11.71)$ & $(8.50)$ & $(5.61)$ & $(0.45)$ & $(5.02)$ \\
\hline SE Clustered By & Firm,Y & Firm,Y & Firm,Y & Firm,Y & Firm,Y \\
$R^{2}$ & 0.10 & 0.06 & 0.05 & 0.20 & 0.02 \\
Firm-Years & 4,846 & 4,846 & 4,846 & 4,846 & 4,846 \\
Firms & 571 & 571 & 571 & 571 & 571 \\
\hline
\end{tabular}

Panel B: Split by size

\begin{tabular}{lrrrrr}
\hline & \multicolumn{1}{c}{ V/D } & \multicolumn{1}{c}{ NPF/D } & \multicolumn{1}{c}{ D/A } & \multicolumn{1}{c}{ (V-NPF)/A } \\
\hline Constant & 25.22 & 1.38 & 23.83 & 37.09 & 8.95 \\
& $(13.08)$ & $(0.87)$ & $(13.78)$ & $(28.79)$ & $(14.46)$ \\
Medium & 10.91 & 7.06 & 3.85 & 1.08 & 1.73 \\
& $(5.68)$ & $(5.34)$ & $(2.36)$ & $(0.67)$ & $(2.27)$ \\
Small & 18.18 & 7.04 & 11.14 & -2.65 & 1.89 \\
& $(8.47)$ & $(4.54)$ & $(5.69)$ & $(-1.45)$ & $(2.47)$ \\
\hline SE Clustered By & Firm,Y & Firm,Y & Firm,Y & Firm,Y & Firm,Y \\
$R^{2}$ & 0.05 & 0.02 & 0.02 & 0.01 & 0.00 \\
Firm-Years & 4,846 & 4,846 & 4,846 & 4,846 & 4,846 \\
Firms & 571 & 571 & 571 & 571 & 571 \\
\hline
\end{tabular}


Figure 2: Exposure to interest rates by credit rating

Notes: The data is annual, and goes from 2003-2013. See Internet Appendix C.1 for more details. This figure separates firms into 6 rating categories, going from 'very good rating' to unrated. IG combines the lowest three rating categories that fall within investment grade (BBB+, BBB, BBB-), and $\mathrm{HY}$ combines the highest three rating categories that fall within high yield (BB+, BB, BB-). Panel A shows the fraction of debt that is floating, in percentage points. Panel B shows floating debt as a fraction of assets, in percentage points. Standard errors are shown based on the standard deviation within each category.

Panel A: Floating debt/Debt

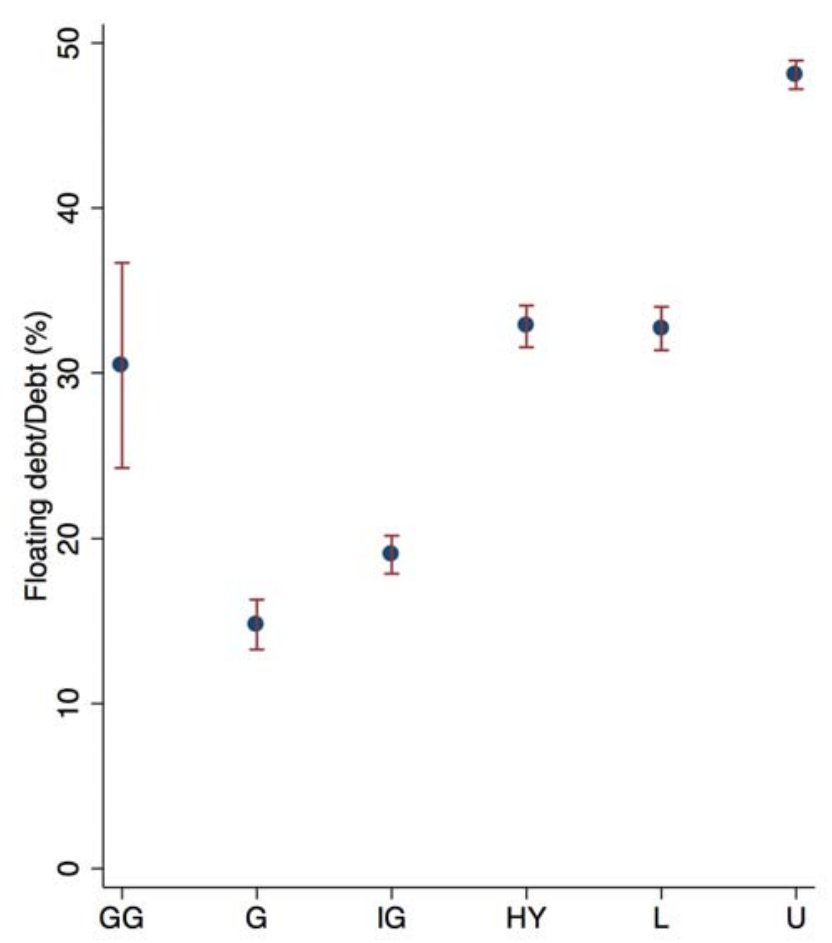

Panel B: Floating debt/Assets

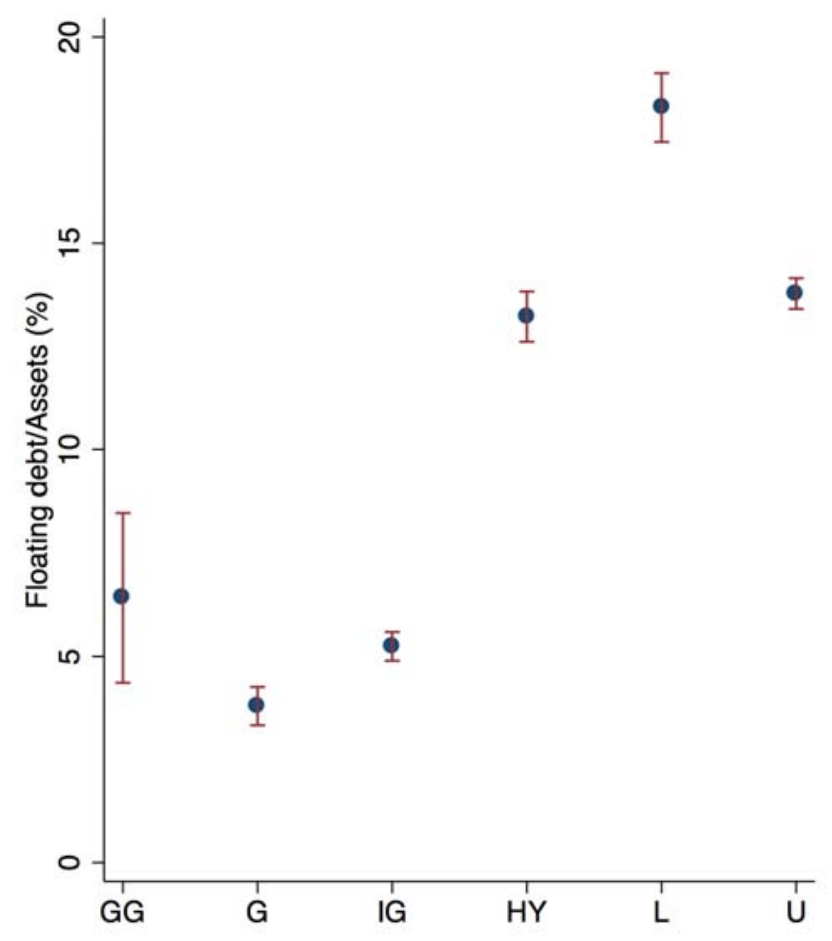


Figure 3: Post-hedging exposure to interest rates by credit rating

Notes: The data is annual, and goes from 2003-2013. See Internet Appendices C.1 and C.2 for more details. This figure restricts to the derivatives-sub-sample, and separates firms into the same 6 rating categories as Figure 2, going from 'very good rating' to unrated. IG combines the lowest three rating categories that fall within investment grade (BBB+, BBB, BBB-), and HY combines the highest three rating categories that fall within high yield (BB+, BB, BB-). Panel A shows the fraction of debt that is floating, in percentage points. Panel B shows post-hedging floating debt as a fraction of assets, in percentage points. Standard errors are shown based on the standard deviation within each category.

Panel A: Floating debt/Debt

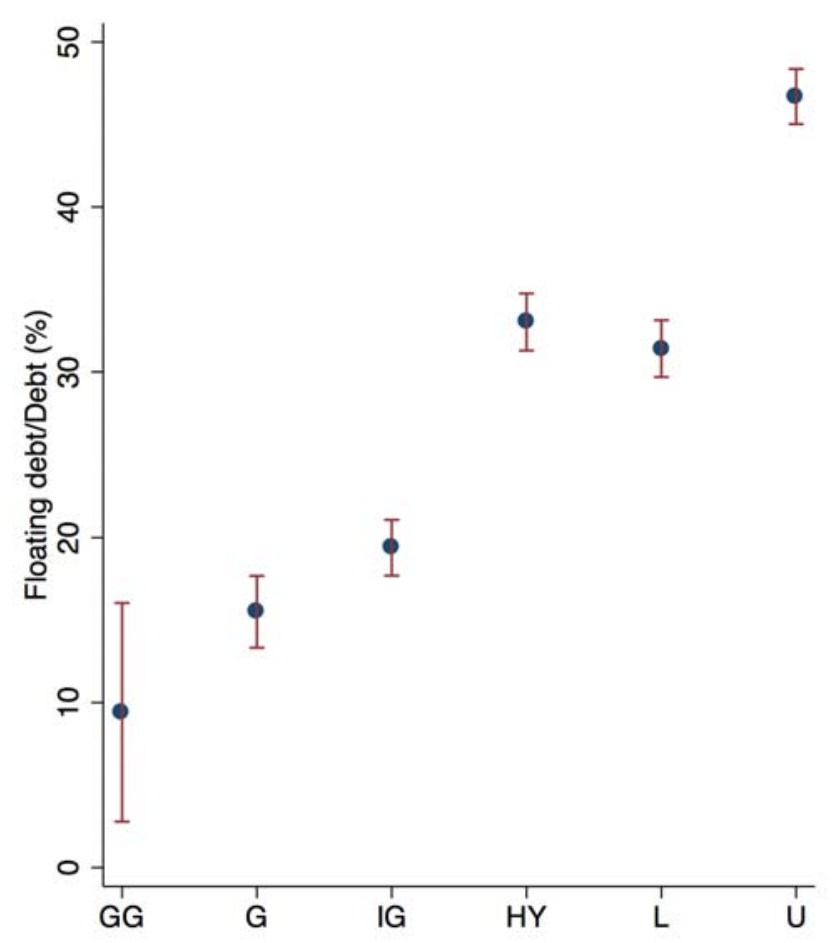

Panel B: PH Floating debt/Assets

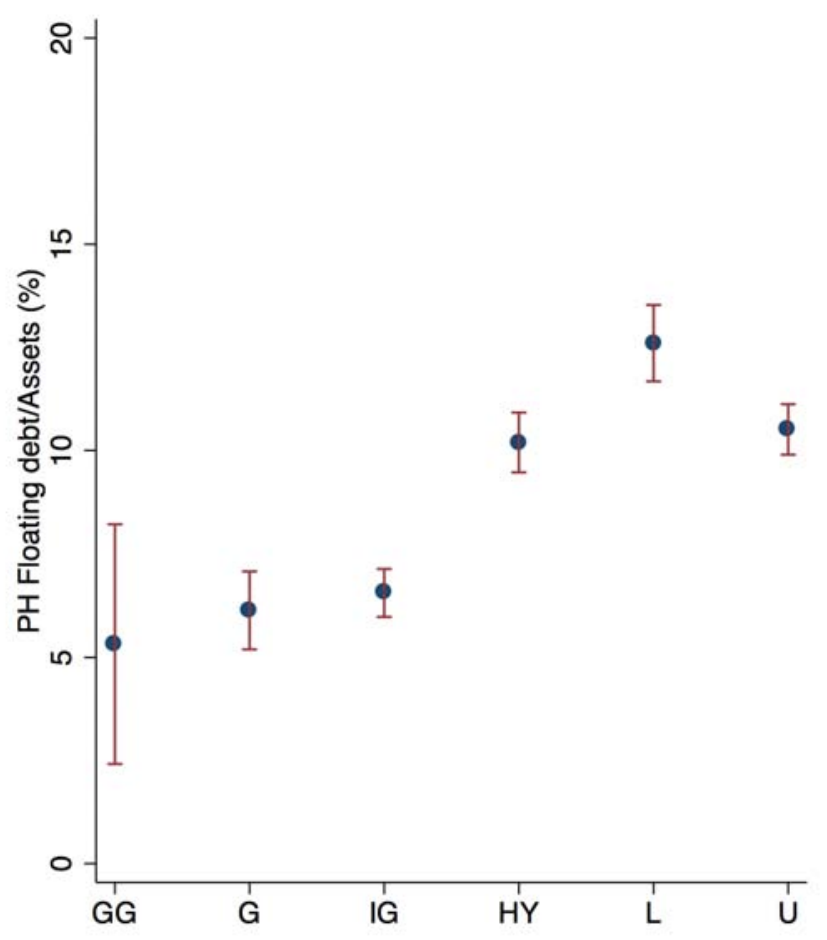


Table 5: Summary statistics for Commercial Bank data

Notes: This table shows summary statistics of US Commercial bank assets for 2001Q1-2014Q4. I use commercial bank level call report data from the FFIEC's website. I aggregate data to the parent holding company level on a pro-forma basis using current ownership from SNL. I include banks that are not owned by a holding company in the sample. I restrict to banks with assets at least $80 \%$ of the minimum requirements for quarterly reporting at the holding company level (150MM in assets prior to 2005Q4, and 500MM subsequently). I also require maturity data to be reported for at least $75 \%$ of loans and securities. See Internet Appendix C.3 for more details. Floating fraction is the reported fraction of loans and securities with maturity or repricing frequency less than three months, in percentage points. Floating fraction (non-res loans) is the corresponding fraction of loans not backed by pass-through mortgages on 1-4 family residences, in percentage points. Floating fraction (non-res securities) is the corresponding fraction of securities not backed by pass-through mortgages on 14 family residences, in percentage points. Implied deposit rate is interest expense on deposits scaled by deposits, annualized and in percentage points. Deposit PT is the coefficient from quarterly bank level regressions of changes in the implied deposit rate on changes in the effective fed funds rate (using data for 2001Q1-2008Q4), in percentage points, winsorized at the $1 \%$ level. I require 20 quarters of data to estimate Deposit PT. Deposit HHI is measured at the county level using branch level deposit data from SNL, aggregated to the parent level weighted by deposits (pro-forma, based on current ownership), expressed as a fraction. Large banks are the largest $5 \%$ of banks by assets in each quarter. I report the standard deviation for each variable (for the full sample).

\begin{tabular}{lrrrr}
\hline & Full Sample & Small Banks & Large Banks & Std. Dev. \\
\hline Assets (BN) & 7.2 & 0.9 & 127.2 & 75.3 \\
Floating fraction & 24.7 & 24.0 & 37.9 & 14.9 \\
Floating fraction (non-res loans) & 34.1 & 33.2 & 51.4 & 17.9 \\
Floating fraction (non-res securities) & 9.0 & 8.5 & 19.3 & 14.6 \\
Deposits/Liabilities & 90.8 & 91.3 & 80.3 & 7.9 \\
Implied Deposit Rate & 1.8 & 1.8 & 1.4 & 1.1 \\
Deposit PT & 28.6 & 28.3 & 33.4 & 9.1 \\
HHI & 0.2 & 0.2 & 0.2 & 0.1 \\
\hline Bank-Quarters & 57,224 & & & \\
Banks & 1,483 & & & \\
\hline
\end{tabular}


Table 6: Floating fraction of bank assets and deposit pass-through (commercial bank data)

Notes: This table shows regressions of the floating mix of bank assets on deposit pass-through, using commercial bank level call report data for 2001Q1-2014Q4. See Internet Appendix C.3 for more details. Panel A focuses on the aggregate balance sheet and on non-residential loans. The first dependent variable (Loans, Sec) is the reported fraction of loans and securities with maturity or repricing frequency less than three months, in percentage points. The second dependent variable (NR Loans) is the corresponding fraction of loans not backed by pass-through mortgages on 1-4 family residences, in percentage points. Deposit PT is the coefficient from quarterly bank level regressions of changes in the implied deposit rate on changes in the effective fed funds rate (using data for 2001Q1-2008Q4), in percentage points, winsorized at the 1\% level. The first two columns show the regressions for the full sample. The third and fourth columns repeat these regressions for 2009Q22014Q4. The final two columns include controls for asset mix (fractions related to C\&I, consumer and real estate lending), available in their present form beginning 2009Q2. Panel B looks at the floating fraction of non-residential securities. All specifications collapse to means at the bank level. $t$-statistics are shown in parentheses.

Panel A: Deposit PT and floating fraction

\begin{tabular}{|c|c|c|c|c|c|c|}
\hline & \multicolumn{2}{|c|}{ 2001Q1-2014Q4 } & \multicolumn{4}{|c|}{ 2009Q2-2014Q4 } \\
\hline & Loans, Sec & NR Loans & Loans, Sec & NR Loans & Loans, Sec & NR Loans \\
\hline Deposit PT & $\begin{array}{r}0.48 \\
(14.40)\end{array}$ & $\begin{array}{r}0.47 \\
(11.88)\end{array}$ & $\begin{array}{r}0.39 \\
(9.33)\end{array}$ & $\begin{array}{r}0.38 \\
(7.28)\end{array}$ & $\begin{array}{r}0.25 \\
(6.30)\end{array}$ & $\begin{array}{r}0.27 \\
(5.25)\end{array}$ \\
\hline Collapsed & Y & $\mathrm{Y}$ & $\mathrm{Y}$ & $\mathrm{Y}$ & $\mathrm{Y}$ & $\mathrm{Y}$ \\
\hline Asset Mix Controls & $\mathrm{N}$ & $\mathrm{N}$ & $\mathrm{N}$ & $\mathrm{N}$ & $\mathrm{Y}$ & $\mathrm{Y}$ \\
\hline$R^{2}$ & 0.12 & 0.09 & 0.08 & 0.05 & 0.24 & 0.15 \\
\hline Bank-Quarters & 57,224 & 57,224 & 18,845 & 18,845 & 18,845 & 18,845 \\
\hline Banks & 1,483 & 1,483 & 956 & 956 & 956 & 956 \\
\hline
\end{tabular}

Panel B: Floating fraction of securities

\begin{tabular}{lrr}
\hline \multicolumn{1}{c}{ NR Securities } & \multicolumn{2}{c}{ NR Securities } \\
\hline Deposit PT & 0.13 & \\
& $(4.72)$ & 0.16 \\
NR Loans (floating fraction) & & $(10.05)$ \\
\hline Collapsed & & Y \\
$R^{2}$ & $\mathrm{Y}$ & 0.06 \\
Bank-Quarters & 0.01 & 57,224 \\
Banks & 57,224 & 1,483 \\
\hline
\end{tabular}


Table 7: Relationship of FRM-ARM spread to deposit pass-through

Notes: This table shows the relationship between the FRM-ARM spread at the bank level and deposit pass-through. I use branch level data on interest rates on jumbo mortgages for the end of 2014 from SNL, and aggregate it to the bank level weighting by the fraction of deposits at different branches. The data includes interest rates for FRMs with different maturities, as well as ARMs and hybrid ARMs (an N/1 ARM has a fixed rate for $N$ years, followed by a floating rate, adjusted once a year). See Internet Appendix C.3 for more details. Deposit PT is the coefficient from quarterly bank level regressions of changes in the implied deposit rate on changes in the effective fed funds rate (using data for 2001Q12008Q4), in percentage points, winsorized at the 1\% level. Panel A shows regressions where the dependent variables are spreads between 15 year FRMs and different types of ARMs. Panel B instead uses spreads relative to 30 year FRMs. All spreads are in basis points. $t$-statistics are shown in parentheses. To provide a sense for data coverage, I also report the fraction of deposits accounted for by branches for which data is available for each regression, in percentage points (Frac deposits).

Panel A: Spread between 15 year FRM and different types of ARMs

\begin{tabular}{lrrrr}
\hline & \multicolumn{1}{c}{ FRM - ARM } & FRM - ARM 3/1 & FRM - ARM 5/1 & FRM - ARM 7/1 \\
\hline Deposit PT & 0.77 & 0.93 & 0.65 & 0.45 \\
& $(0.82)$ & $(2.11)$ & $(1.80)$ & $(1.51)$ \\
\hline$R^{2}$ & 0.01 & 0.02 & 0.01 & 0.01 \\
Banks & 104 & 265 & 419 & 296 \\
Frac deposits (\%) & 4 & 22 & 65 & 63 \\
\hline
\end{tabular}

Panel B: Spread between 30 year FRM and different types of ARMs

\begin{tabular}{lrrrr}
\hline & \multicolumn{1}{c}{ FRM - ARM } & FRM - ARM 3/1 & FRM - ARM 5/1 & FRM - ARM 7/1 \\
\hline Deposit PT & 0.46 & 0.76 & 0.67 & 0.43 \\
& $(0.50)$ & $(1.76)$ & $(1.94)$ & $(1.44)$ \\
\hline$R^{2}$ & 0.00 & 0.01 & 0.01 & 0.01 \\
Banks & 104 & 265 & 419 & 296 \\
Frac deposits (\%) & 4 & 22 & 65 & 63 \\
\hline
\end{tabular}


Table 8: Bank competition, pass-through and asset mix (commercial bank data)

Notes: This table shows the relationship between deposit pass-through, competition, and floating mix of bank assets, using commercial bank level call report data for 2001Q1-2014Q4. See Internet Appendix C.3 for more details. Panel A focuses on the relationship between pass through, HHI, and bank size. Cross sectional regressions collapse the sample to means at the bank level. Panel regressions instead include quarter and bank fixed effects. Deposit PT is the coefficient from quarterly bank level regressions of changes in the implied deposit rate on changes in the effective fed funds rate (using data for 2001Q1-2008Q4), in percentage points, winsorized at the 1\% level. Deposit HHI is measured at the county level using branch level deposit data, aggregated to the parent level weighted by deposits (pro-forma, based on current ownership), expressed as a fraction. Log(Assets) is the base-10 logarithm of assets. $\Delta$ Deposit rate is the quarterly change in the implied deposit rate. $\triangle F F$ is the change in the quarterly average effective federal funds rate. Panel B uses HHI as an instrument for deposit pass-through. The first three columns repeat OLS regressions from Table 6. The dependent variables are the floating fraction of all loans and securities, non-residential loans and non-residential securities respectively. The fourth column repeats the first stage from Panel A and shows the $F$-statistic. The final three columns use HHI as an instrument for Deposit PT in 2SLS estimation. Standard errors are clustered by bank for panel regressions. $t$-statistics are shown in parentheses.

Panel A: Deposit pass-through, competition and bank size

\begin{tabular}{|c|c|c|c|c|}
\hline & \multicolumn{2}{|c|}{ Collapsed cross section } & \multicolumn{2}{|c|}{ Panel } \\
\hline & Deposit PT & Deposit PT & $\Delta$ Deposit rate & $\Delta$ Deposit rate \\
\hline HHI & $\begin{array}{l}-10.30 \\
(-4.77)\end{array}$ & $\begin{array}{r}-8.77 \\
(-4.02)\end{array}$ & $\begin{array}{r}-0.06 \\
(-1.54)\end{array}$ & $\begin{array}{r}-0.05 \\
(-1.44)\end{array}$ \\
\hline Log(Assets) & & $\begin{array}{r}0.79 \\
(4.01)\end{array}$ & & $\begin{array}{r}-0.00 \\
(-0.32)\end{array}$ \\
\hline$\Delta \mathrm{FF} \times \mathrm{HHI}$ & & & $\begin{array}{r}-0.12 \\
(-4.80)\end{array}$ & $\begin{array}{r}-0.09 \\
(-3.91)\end{array}$ \\
\hline$\Delta \mathrm{FF} \times \log ($ Assets $)$ & & & & $\begin{array}{r}0.02 \\
(5.55)\end{array}$ \\
\hline Collapsed & $\mathrm{Y}$ & $\mathrm{Y}$ & $\mathrm{N}$ & $\mathrm{N}$ \\
\hline Quarter FE & $\mathrm{N}$ & $\mathrm{N}$ & $\mathrm{Y}$ & $\mathrm{Y}$ \\
\hline Bank FE & $\mathrm{N}$ & $\mathrm{N}$ & $\mathrm{Y}$ & $\mathrm{Y}$ \\
\hline SE Clustered by & - & - & Bank & Bank \\
\hline$R^{2}$ & 0.02 & 0.03 & 0.33 & 0.33 \\
\hline Bank-Quarters & 57,224 & 57,224 & 55,245 & 55,245 \\
\hline Banks & 1,483 & 1,483 & 1,483 & 1,483 \\
\hline
\end{tabular}


Panel B: HHI as an instrument for Deposit PT

\begin{tabular}{|c|c|c|c|c|c|c|c|}
\hline & \multicolumn{3}{|c|}{ OLS } & \multirow{2}{*}{$\frac{\text { First Stage }}{\text { Deposit PT }}$} & \multicolumn{3}{|c|}{ IV } \\
\hline & Loans, Sec & NR Loans & NR Securities & & Loans, Sec & NR Loans & NR Securities \\
\hline Deposit PT & $\begin{array}{r}0.48 \\
(14.40)\end{array}$ & $\begin{array}{r}0.47 \\
(11.88)\end{array}$ & $\begin{array}{r}0.13 \\
(4.72)\end{array}$ & & $\begin{array}{r}1.79 \\
(4.63)\end{array}$ & $\begin{array}{r}0.99 \\
(2.92)\end{array}$ & $\begin{array}{r}1.36 \\
(4.01)\end{array}$ \\
\hline HHI & & & & $\begin{array}{l}-10.30 \\
(-4.77)\end{array}$ & & & \\
\hline Collapsed & $\mathrm{Y}$ & $\mathrm{Y}$ & $\mathrm{Y}$ & $\mathrm{Y}$ & $\mathrm{Y}$ & $\mathrm{Y}$ & $Y$ \\
\hline$R^{2}$ & 0.12 & 0.09 & 0.01 & 0.02 & & & \\
\hline$F$ & & & & 22.77 & & & \\
\hline Bank-Quarters & 57,224 & 57,224 & 57,224 & 57,224 & 57,224 & 57,224 & 57,224 \\
\hline Banks & 1,483 & 1,483 & 1,483 & 1,483 & 1,483 & 1,483 & 1,483 \\
\hline
\end{tabular}


Table 9: Summary statistics for Bank Holding Company data

Notes: This table shows summary statistics of US Bank Holding Company balance sheets for 1986Q3-2014Q4. I use BHC level call report data from the Chicago Fed's website. I aggregate data pro-forma to present ownership using data on BHC mergers from the Chicago Fed's website. I restrict to BHCs with assets above the minimum requirements for quarterly reporting (150MM in assets prior to 2005Q4, and 500MM subsequently). See Internet Appendix C.4 for more details. Total assets $\leq 1 \mathrm{Yr}$ is the fraction of assets with maturity or repricing frequency less than one year, in percentage points. Loans and securities $\leq 1 \mathrm{Yr}$ is the corresponding inferred fraction of loans and securities (i.e. net of interest-bearing cash and federal fund and repo assets), in percentage points. Loans $\leq 1 \mathrm{Yr}$ is the corresponding inferred fraction of loans (i.e. net of interest-bearing cash, federal funds, and repo assets and debt securities with maturity or repricing frequency less than one year), in percentage points. I require these ratios to be positive and less than $110 \%$. Implied deposit rate is interest expense on deposits scaled by deposits, annualized and in percentage points. Deposit PT is the coefficient from rolling quarterly bank level regressions of changes in the implied deposit rate on changes in the effective fed funds rate (using data from the previous 8-20 quarters, as available), in percentage points, winsorized at the 1\% level. Large banks are the largest 5\% of banks by assets in each quarter. I report the standard deviation for each variable for the full sample.

\begin{tabular}{lrrrr}
\hline & Full Sample & Small Banks & Large Banks & Std. Dev. \\
\hline Assets (BN) & 4.2 & 1.2 & 51.8 & 23.1 \\
Total $\leq 1$ Yr $(\%)$ & 43.3 & 42.9 & 49.7 & 16.0 \\
Loans and securities $\leq 1$ Yr (\%) & 40.8 & 40.5 & 47.2 & 16.2 \\
Loans $\leq 1$ Yr (\%) & 50.9 & 50.2 & 61.2 & 25.4 \\
Deposits/Liabilities & 89.1 & 89.9 & 76.9 & 9.9 \\
Implied Deposit Rate & 2.6 & 2.6 & 2.5 & 1.5 \\
Deposit PT & 26.9 & 26.5 & 33.7 & 21.5 \\
\hline Bank-Quarters & 78,160 & & & \\
Banks & 1,912 & & & \\
\hline
\end{tabular}


Table 10: Floating mix of bank assets and deposit pass-through (BHC data)

Notes: This table shows regressions of the floating mix of bank assets on deposit pass-through, using bank holding company level call report data for 1986Q3-2014Q4. See Internet Appendix C.4 for more details. Panel A shows the relationship between the floating fraction of assets and deposit pass-through. The first dependent variable (All) is the fraction of total assets with maturity or repricing frequency less than one year, in percentage points. The second dependent variable (Loans, $\mathrm{Sec}$ ) is the corresponding inferred fraction of loans and securities (i.e. net of interest-bearing cash and federal fund and repo assets), in percentage points. The third dependent variable (Loans) is the corresponding inferred fraction of loans (i.e. net of interest-bearing cash, federal fund and repo assets, and debt securities with maturity or repricing frequency less than one year), in percentage points. Deposit PT is the coefficient from rolling quarterly bank level regressions of changes in the implied deposit rate on changes in the effective fed funds rate (using data from the previous 8-20 quarters, as available), in percentage points, winsorized at the 1\% level. Panel B shows the relationship between deposit pass-through and bank size. $\log$ (Assets) is the base-10 logarithm of assets. Standard errors are double clustered by Quarter and Bank. $t$-statistics are shown in parentheses.

Panel A: Variation of floating mix within Quarter and Bank

\begin{tabular}{lrrrrrr}
\hline & All & Loans, Sec & \multicolumn{1}{l}{ Loans } & \multicolumn{1}{l}{ All } & Loans, Sec & \multicolumn{1}{l}{ Loans } \\
\hline Deposit PT & 0.10 & 0.10 & 0.13 & 0.02 & 0.02 & 0.00 \\
& $(6.75)$ & $(6.75)$ & $(5.82)$ & $(2.59)$ & $(2.50)$ & $(0.29)$ \\
\hline Quarter FE & $\mathrm{Y}$ & $\mathrm{Y}$ & $\mathrm{Y}$ & $\mathrm{Y}$ & $\mathrm{Y}$ & $\mathrm{Y}$ \\
Bank FE & $\mathrm{N}$ & $\mathrm{N}$ & $\mathrm{N}$ & $\mathrm{Y}$ & $\mathrm{Y}$ & $\mathrm{Y}$ \\
SE Clustered by & Q, Bank & Q, Bank & Q, Bank & Q, Bank & Q, Bank & Q, Bank \\
$R^{2}$ & 0.15 & 0.17 & 0.11 & 0.72 & 0.71 & 0.61 \\
BHC-Quarters & 78,160 & 78,160 & 78,160 & 78,160 & 78,160 & 78,160 \\
BHCs & 1,912 & 1,912 & 1,912 & 1,912 & 1,912 & 1,912 \\
\hline
\end{tabular}

Panel B: Deposit pass-through and bank size

\begin{tabular}{lrr}
\hline & Deposit PT & Deposit PT \\
\hline Log(Assets) & 1.61 & 1.57 \\
& $(6.57)$ & $(1.42)$ \\
\hline Quarter FE & $\mathrm{Y}$ & $\mathrm{Y}$ \\
Bank FE & $\mathrm{N}$ & $\mathrm{Y}$ \\
SE Clustered by & Q, Bank & Q, Bank \\
$R^{2}$ & 0.17 & 0.46 \\
Bank-Quarters & 78,160 & 78,160 \\
Banks & 1,912 & 1,912 \\
\hline
\end{tabular}


Table 11: Sensitivity of implied loan rates to short-term interest rates

Notes: I use historical data on bank balance sheets from 1934-2013 from the FDIC. The data contains annual aggregate information for all US commercial banks with deposit insurance over this period. I calculate an inferred loan rate, $y_{t}$, as the ratio of interest income on loans and leases to net loans and leases. I use the yield on three month Treasury Bills (from the Federal Reserve) as a proxy for the short-term rate $r_{t}$. See Internet Appendix C.5 for more details. I run regressions of the form

$$
\Delta y_{t}=\alpha+\beta \Delta r_{t}+\rho \Delta y_{t-1}
$$

for different sub-samples: 1934-1969 and 1970-2013. The table also shows the long term response of loan rates, $\beta /(1-\rho)$. The table shows $t$-statistics based on Newey-West standard errors, allowing autocorrelation up to five lags.

\begin{tabular}{lrr}
\hline & $1934-1969$ & $1970-2013$ \\
\hline$\Delta r_{t}$ & 0.24 & 0.47 \\
& $(3.08)$ & $(11.25)$ \\
$\Delta y_{t-1}$ & 0.37 & 0.30 \\
& $(3.14)$ & $(4.17)$ \\
\hline$\beta /(1-\rho)$ & 0.37 & 0.67 \\
\hline$R^{2}$ & 0.27 & 0.79 \\
$\mathrm{~N}$ & 34 & 44 \\
\hline
\end{tabular}

